\title{
Quaternary geology of western and central North Greenland
}

G E U S

Report file no.

22490

M. Kelly and O. Bennike
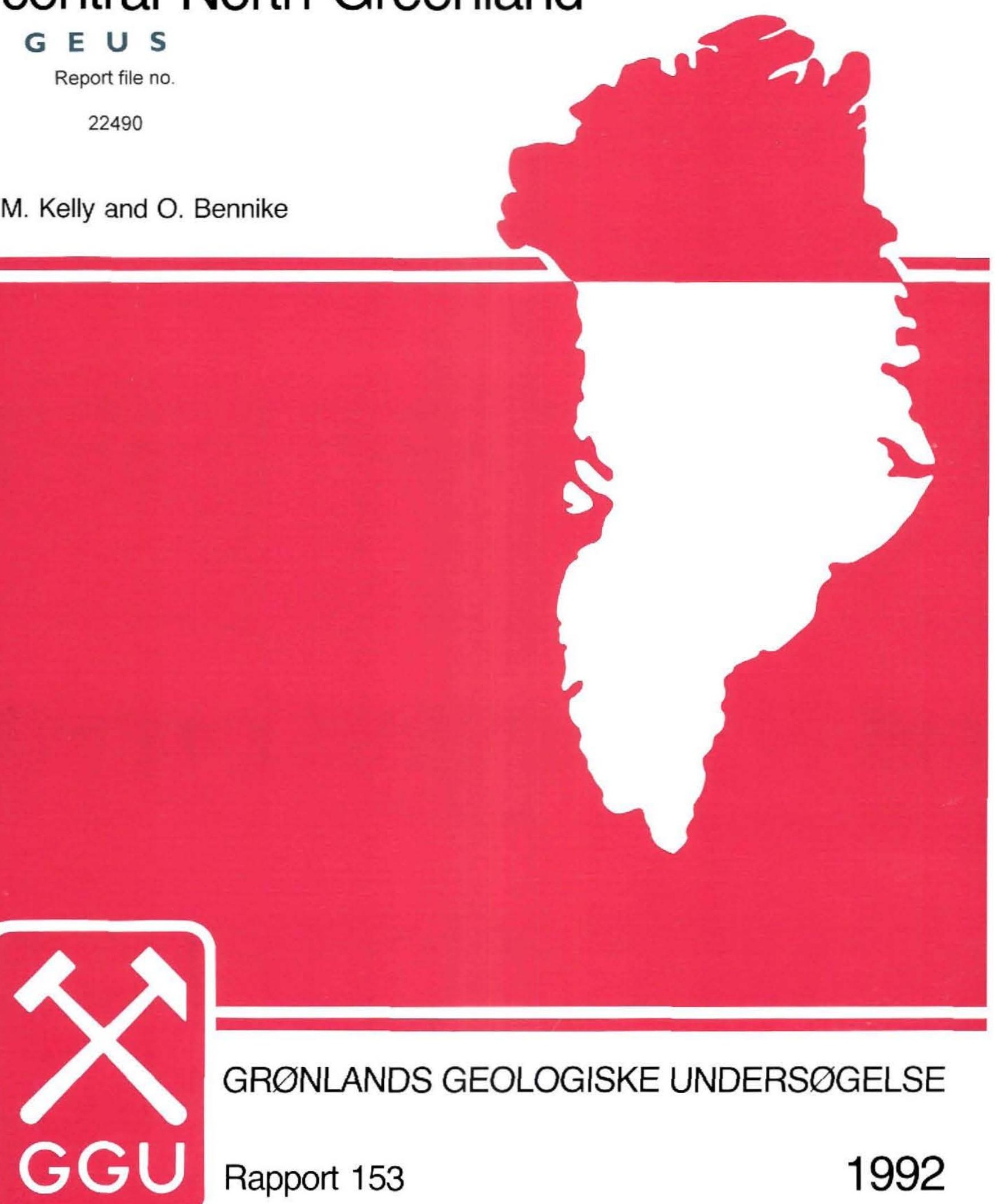

GRØNLANDS GEOLOGISKE UNDERSØGELSE

Rapport 153

1992 


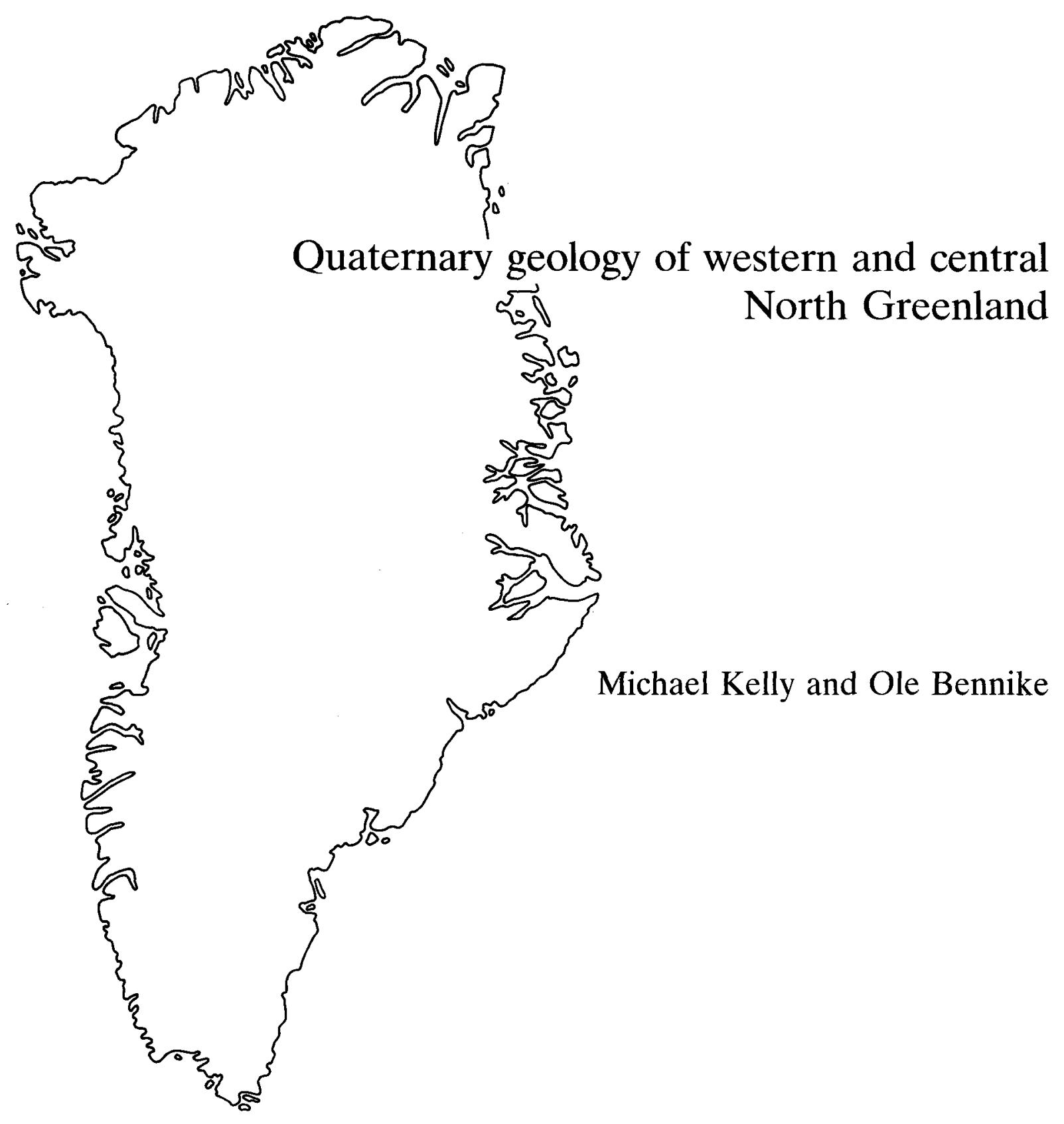


Kelly, M. \& Bennike, O. 1992: Quaternary geology of western and central North Greenland. Rapp. Grønlands geol. Unders. 153, $34 \mathrm{pp}$.

The earliest Quaternary event represented is the Kap Bryant glacial stade of probable Saalian age, in which an ice sheet covered the area out to the shelf. In contrast, in the Late Weichselian Kap Fulford stade, the area was only partly glaciated, with outlet lobes from an ice sheet occupying the outer fjords. There is some evidence of an earlier (Early Weichselian?) slightly more extensive glaciation (Kap Sumner stade). In the early Holocene, the ice margin had retreated to the middle regions of the fjords and extensive glacial lakes were formed in intervening areas. The Late Holocene Steensby stade produced a readvance of the ice sheet at the head of the fjords and the growth of local ice caps.
Reworked marine fossils in glacial sediments define the Hall Land marine event of Eemian and/or Early Weichselian age. The Late Weichselian/Holocene marine event (Nyeboe Land event) is abundantly represented by deposits whose distribution shows that the limit of transgression varied over the area, with a maximum at about $125 \mathrm{~m}$ above sea level. Regression from this limit occurred during the Holocene, initially at a slow rate. The fossil biota are described from the marine sediments and from a small number of terrestrial occurrences.

\section{Authors' addresses:}

M. K., Division of Environmental Sciences, Lancaster University, Lancaster LA1 4YQ, U.K.

O. B., Geological Museum, Øster Voldgade 5-7, DK-1350 Copenhagen K, Denmark.

\section{Dansk sammendrag}

Det ældste Kvartær er repræsenteret ved Kap Bryant glaciale stadium, sandsynligvis af saale alder, hvorunder isen dxkkede området ud til shelfen. Under Kap Fulford-stadiet i sen Weichsel var området derimod kun delvist gletscherdækket med udløbere fra et isdække, som omfattede de ydre fjorde. Der er visse tegn på en tidligere (tidlig Weichsel?), mere udbredt gletscherdækning (Kap Sumner-stadiet). I tidlig Holocæn havde isranden trukket sig tilbage til den midterste del af fjordene, og store smeltevandssøer dannedes i de mellemliggende områder. Under Steensby-stadiet i sen Holocæn indtraf atter et fremstød af Indlandsisens rand i den inderste del fjordene, og der foregik en vækst af de lokale iskapper. Omlejrede marine fossiler i smeltevandssedimenter angiver alderen af den marine transgression i Hall Land til at være Eem og/eller tidlig Weichsel. Den marine transgression i sen Weichsel/Holocan (Nyeboe Land-transgressionen) er velrepræsenteret i form af aflejringer, hvis fordeling viser, at grænsen for transgressionen i området var underkastet variationer med et maksimum på $125 \mathrm{~m}$ over havniveau. Regressionen fra denne grænse foregik i Holocæn initialt med en lille hæuningsrate. Fossilfaunaen er beskrevet på grundlag af marine sedimenter og et lille antal terrestriske forekomster.

\section{Imaqarnersiuineq}

Kvartærip aallartinnerata nalaa, tassa Nunarsuup ingerlaasiani immikkoortoq maanna atuuttoq, qularnanngitsumik saalip nalaani Kap Bryantimi sermersuaqarneranik immikkoortinneqarsinnaavoq. Tamatumalu nalaani sermersuup nunarput ikkannersuit tikillugit matusimavaa. Weishelip naalernerani Kap Fulfordip nalaani, tassa kingullermik sermersuaqarnerata nalaani, nuna tamassuma ilaanna sermersuup matusimasimava, kangerluillu avalliit sermeqarfiusumit ningimaneqarfiusimallutik. Arlalitsigut siusinnerusumik (Weichelip aallartinnerani?) suli annertunerusumik sermersuaqarsimaneranik (Kap Sumnerip nalaani) takussutissaqarpoq. Holocanip aallartinnerani sermip killinga kangerluit qeqqa tikillugu aassimavoq, tamakkulu akornanni tasersuarpassuit sermip aannerata kinguneranik pinngorsimapput. Holocænip naalernerani, immikkoortup
Steensbymik taaguutillip nalaani kangerlunni qinngorlinni Sermersuup killinga avasilleqqissimavoq, sermersuaqarfiillu immikkoortut arlallit pinngorsimallutik. Immap uumasui ujaranngorsimasut, sermip aannerata nalaani kinnganernut pinngortunut akulerussimasut ersersippaat, Hall Landimi immap killingata qaffannera Eemip aammalu/imaluunniit Weichelip aallartinnerata nalaani pisimasoq. Weichelip naalernerani/Holocænimilu immap killingata qaffannera (Nyeboe Landip qaffanneranik taaguutillip) annertunerpaamik 125 meterit tikillugit tamaani allanngorarsimasoq nunami kinnganerit kiviorarsimasut ersersippaat. Immap killingata appariarnera Holocænip nalaani arriitsumik pisimavoq. Taamanilu uumasuusimasut ujaranngorsimasut imaani kinnganernit nunallu qaani qaleriissunit siumorneqarsimapput. 


\section{Contents}

Dansk sammendrag - Imaqarnersiuineq . . . . . . .

Introduction . . . . . . . . . . . . . . 5

Bedrock geology and physiography ....... 5

Previous work $\ldots \ldots \ldots \ldots \ldots \ldots \ldots \ldots \ldots$

Methods ................... 8

Stratigraphy ...................

Kap Bryant stade (Saalian?) . . . . . . . . . . 9

Hall Land marine event (Eemian - Early Weichselian?).

Kap Sumner stade (Early Weichselian?). . . . . . 11

Non-glacial terrestrial facies (Weichselian). . . . 12

Kap Fulford stade (Late Weichselian). . . . . . . 12

Nyeboe Land marine event (end Weichselian Holocene) .................... 14

Distribution and marine limit .......... 14

Sea level change and emergence $\ldots \ldots \ldots \ldots 16$
Warming Land stade (Early Holocene)...... 17

Steensby stade (Late Holocene) . . . . . . . . . . 20

Alternative stratigraphic models. . . . . . . . 21

Reconstructed ice margins and profiles...... 23

History and environmental evidence of biota ... 24

Pre-Holocene marine biota . . . . . . . . . . . 24

Holocene marine biota . . . . . . . . . . . 24

Holocene driftwood ................. 25

Pre-Holocene terrestrial biota. . . . . . . . . . 25

Holocene terrestrial biota . . . . . . . . . 25

Regional correlation ............... 28

Acknowledgements ................ 30

References ...................... 30

\section{Grønlands Geologiske Undersøgelse Ujarassiortut Kalaallit Nunaanni Misissuisoqarfiat Geological Survey of Greenland}

The Geological Survey of Greenland (GGU) is a research institute affiliated to the Mineral Resources Administration for Greenland (MRA) within the Danish Ministry of Energy. As with all other activities involving the non-living resources in Greenland, GGU's investigations are carried out within the framework of the policies decided jointly by the Greenland Home Rule Authority and the Danish State. 


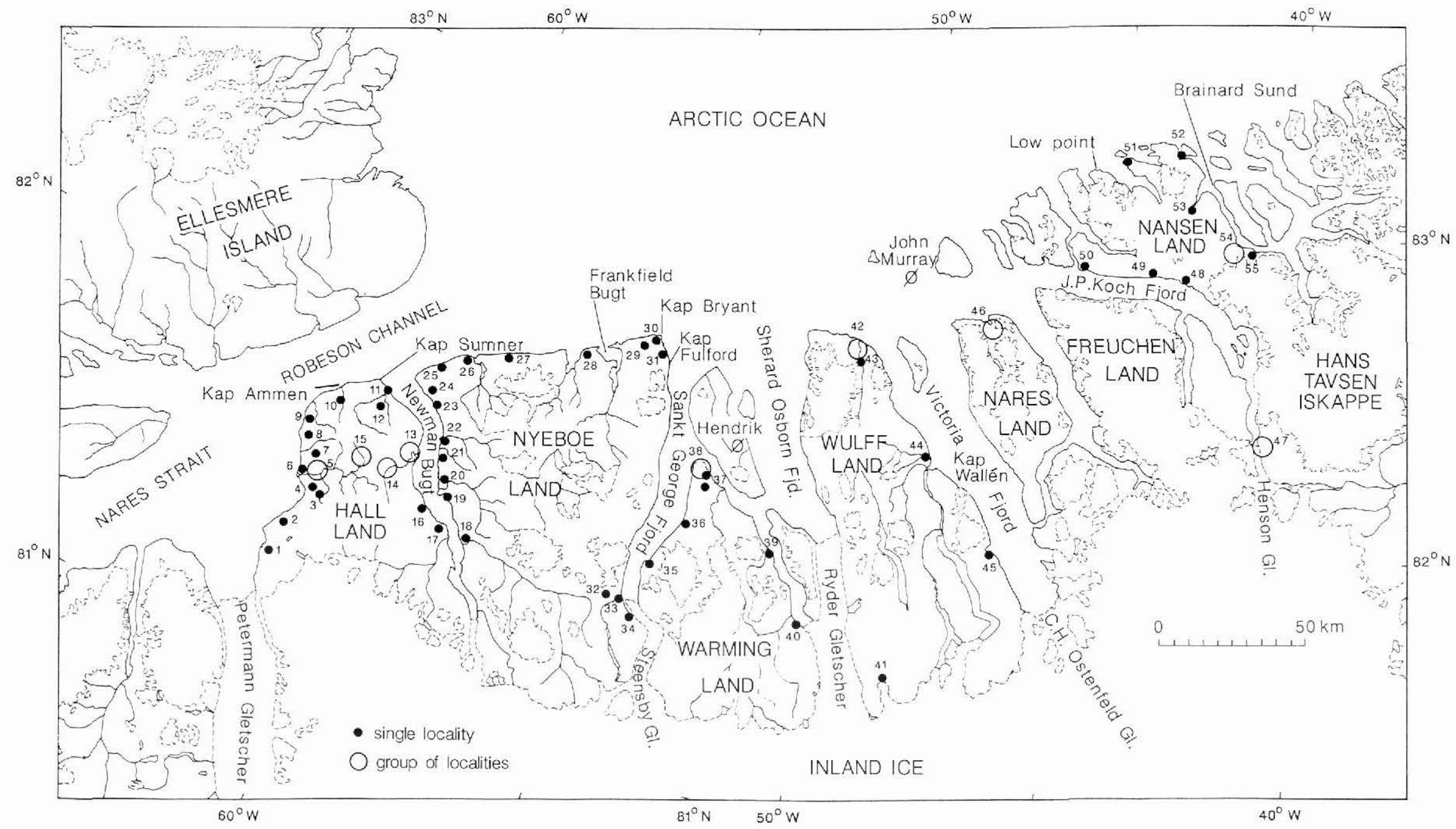

Fig. 1. Locality map for western and central North Greenland. 


\section{Introduction}

In 1984 a reconnaissance survey of the Quaternary geology of a large part of western and central North Greenland (Fig. 1) was carried out as part of the North Greenland Project of the Geological Survey of Greenland. A preliminary account of some of the results has been published in Kelly \& Bennike (1985) and Bennike \& Kelly (1987).

\section{Bedrock geology and physiography}

The area, stretching from Hall Land in the west to Nansen Land in the east, forms a strip of land $375 \mathrm{~km}$ long by $100-150 \mathrm{~km}$ wide between the Arctic Ocean and the Greenland ice sheet. Northerly trending steep-sided fjords divide it into a number of peninsulas and large islands. The major bedrock stratigraphic units strike approximately E-W (Henriksen, 1987), resulting in a $\mathrm{N}-\mathrm{S}$ contrast in the bedrock related topography along the peninsulas.

The northern parts of the peninsulas west of Nansen Land consist of folded Silurian trough facies turbidites and mudstones with lesser amounts of Cambro-Ordovician deep water siliciclastic rocks. The topography of these areas is mainly gently rounded hills and plateaux around $200-400 \mathrm{~m}$ altitude, with a northern zone of higher hills around $600-1000 \mathrm{~m}$ above sea level. Rivers flowing to the north across this zone tend to have deeply incised sections cut in the floor of broader U-shaped valleys. Broad lowland areas stretch across the middle parts of several peninsulas, e.g. Hall Land, Wulff Land and Nansen Land, and wide shallow valleys occur in the interior of Nyeboe Land. The morphology of the northwest end of Nansen Land, which is underlain by Cambrian trough facies, is completely different in having a highly fretted landscape, with dendritic valley systems separated by narrow ridges. A number of broader linear valleys cut through that area.

The southern parts of the peninsulas consist of unfolded Cambrian to Silurian shelf facies carbonates with minor amounts of siliciclastic rocks, which form flat plateaux around 400-800 $\mathrm{m}$ above sea level, dissected by narrow $U$-shaped valleys with a mainly northerly trend.

At the head of Victoria Fjord are small outcrops of Precambrian gneisses. On the evidence of the distribution of gneiss erratics, crystalline rocks of the Greenland Shield must occur extensively beneath the ice sheet between Hall Land and Wulff Land. Banded ironstone erratics in southern Hall Land are similar to rocks from the Precambrian of the Thule district (Dawes \& Frisch,
1981), indicating the existence of rocks of this age beneath the ice to the south.

Northward flowing outlet glaciers from the Greenland ice sheet (Inland Ice) occupy the inner parts of all the major fjords. They are relatively active with surface velocities of 300-900 m/a (Higgins, 1988) and, characteristically, have large thin and partially disjointed terminal zones, due to inhibition of calf ice production by the sea-ice, which is semi-permanent in the fjords, but not in Nares Strait (Koch, 1928a). Local ice caps are common on the higher ground throughout the area, some in the east having small outlet glaciers which reach the sea. The largest ice caps are the Hans Tavsen Iskappe and the ice cap which almost entirely covers Freuchen Land, both in the north-east of the region.

\section{Previous work}

Because of the remoteness and inaccessibility of the region, the study of its Quaternary geology has been sporadic, although it has a long history. The first expedition to Hall Land, by the United States North Polar Expedition of 1871-1873, described the presence of raised marine and littoral deposits with shells and driftwood, as well as the occurrence of erratics (Bessels, 1879). The erratics, however, were interpreted as the products of rafting by icebergs or sea-ice (Bessels, 1879; Feilden, 1895). Subsequent investigations have continued to concentrate on the more accessible western part of the region, especially Hall Land.

Systematic geological surveys were first made in the region by Lauge Koch in 1917 and 1922, using dog sledges (Koch, 1928a, b). The modern period of geological investigations, based largely on air transport, began in 1958, with fieldwork by the United States Geological Survey during military operations. This resulted in a map and account of the surficial geology of Hall Land (Davies et al., 1959; Davies, 1963, 1972). Subsequently, work has been carried out by geologists of the Geological Survey of Greenland. Weidick (1971, $1972,1975,1976)$ reviewed the older data and, later, visited several sites in the area (Weidick, 1977a, b, 1978a, b), and Dawes $(1977,1987)$ produced a description and detailed map of the geology of Hall Land from field work in 1965 and extensive photo-geological mapping. More recently, England $(1985,1987)$ extended his investigations of the Quaternary geology of Ellesmere Island in Canada to the adjacent areas of Hall Land and Nyeboe Land.

The essential features of the glacial stratigraphy of 
Table 1. Radiocarbon dates, western and central North Greenland

\begin{tabular}{|c|c|c|c|c|c|c|c|c|c|c|}
\hline \multirow{2}{*}{$\begin{array}{l}\text { Loc } \\
\text { no. }\end{array}$} & \multirow[t]{2}{*}{ Area } & \multirow{2}{*}{$\begin{array}{c}\text { Height } \\
\text { m }\end{array}$} & \multirow{2}{*}{$\begin{array}{c}\text { Sample } \\
\text { no. GGU }\end{array}$} & \multirow[t]{2}{*}{ Material } & \multirow[t]{2}{*}{ Lab. no. } & \multicolumn{4}{|c|}{ C-14 data } & \multirow[t]{2}{*}{ Reference } \\
\hline & & & & & & $\begin{array}{c}\text { Delta } \\
\text { C-13 } \\
\%\end{array}$ & $\begin{array}{l}\text { Lab. } \\
\text { age } \\
\text { y BP }\end{array}$ & $\begin{array}{c}1 \text { sigma } \\
y\end{array}$ & $\begin{array}{l}\text { Reservoir } \\
\text { corrected } \\
\text { age y BP }\end{array}$ & \\
\hline 1 & Hall Ld & 69 & 313920 & shell & HAR-6295 & +2.3 & 8040 & 150 & 7490 & Kelly \& Bennike, 1985 \\
\hline \multirow[t]{2}{*}{1} & Hall Ld & 68 & & shell & SI-5857 & & 8225 & 95 & $?$ & England, 1985 \\
\hline & & & & replicate & $S-2409$ & & 7840 & 125 & 7690 & England, 1985 \\
\hline 3 & Hall Ld & 122 & & shell & S-2303 & & $>33000$ & & & England, 1985 \\
\hline 5 & Hall Ld & 82 & 313883 & shell & HAR-6293 & +1.9 & 8420 & 200 & 7870 & Kelly \& Bennike, 1985 \\
\hline 5 & Hall Ld & 105 & 313876 & shell & HAR-6292 & +2.1 & 8090 & 120 & 7540 & Kelly \& Bennike, 1985 \\
\hline 5 & Hall Ld & 73 & 313877 & shell & $\mathrm{K}-4377$ & +1.0 & 8080 & 115 & 7930 & Bennike \& Kelly, 1987 \\
\hline 5 & Hall Ld & 44 & 313882 & shell & Ua-1228 & & 8555 & 160 & 8005 & This work \\
\hline 5 & Hall Ld & 20 & & shell & SI-5855 & & 8280 & 90 & $?$ & England, 1985 \\
\hline 5 & Hall Ld & 56 & & wood & $S-2313$ & & 8295 & 120 & & England, 1985 \\
\hline 5 & Hall Ld & 72 & & shell & S-2312 & & 6560 & 185 & 6410 & England, 1985 \\
\hline 5 & Hall Ld & 102 & & shell & S-2317 & & 7385 & 190 & 7235 & England, 1985 \\
\hline 5 & Hall Ld & 77 & & shell & S-2306 & & 7745 & 135 & 7595 & England, 1985 \\
\hline 6 & Hall Ld & $23-30$ & & bone & $\mathrm{K}-3366$ & & 3870 & 85 & & Knuth, 1981 \\
\hline 7 & Hall Ld & 139 & 313892 & shell & HAR-6809 & +1.5 & $>27500$ & & & Bennike \& Kelly, 1987 \\
\hline 10 & Hall Ld & 76 & 313914 & shell & K-4379 & +1.6 & 7740 & 115 & 7590 & Bennike \& Kelly, 1987 \\
\hline 12 & Hall Ld & 227 & 313858 & shell & HAR-6808 & +1.5 & $>27500$ & & & Bennike \& Kelly, 1987 \\
\hline 13 & Hall Ld & 101 & 313900 & shell & K-4378 & +1.9 & 8640 & 115 & 8490 & Bennike \& Kelly, 1987 \\
\hline 13 & Hall Ld & 89 & 313896 & shell & HAR-6745 & +1.3 & 8870 & 100 & 8320 & Bennike \& Kelly. 1987 \\
\hline 13 & Hall Ld & 89 & 313897 & bone & K-4687 & -16.6 & 8680 & 120 & & Bennike \& Kelly, 1987 \\
\hline 13 & Hall Ld & 14 & & shell & S-2315 & & 8525 & 285 & 8375 & England, 1985 \\
\hline 13 & Hall Ld & 14 & & syphons & $S-2316$ & & 9355 & 1325 & & England, 1985 \\
\hline 13 & Hall Ld & 82 & & shell & SI-5854 & & 8560 & 75 & $?$ & England, 1985 \\
\hline 13 & Hall Ld & 142 & & shell & S-2304 & & $>33000$ & & & England, 1985 \\
\hline 13 & Hall Ld & 10 & & shell & S-2314 & & 4690 & 165 & 4540 & England, 1985 \\
\hline 13 & Hall Ld & 8 & & shell & S-2305 & & 5765 & 100 & 5615 & England, 1985 \\
\hline \multirow[t]{2}{*}{13} & Hall Ld & 55 & & shell & S-2301 & & 7965 & 115 & 7815 & England, 1985 \\
\hline & & & & replicate & SI-5853 & & 8685 & 90 & $?$ & England, 1985 \\
\hline \multirow[t]{3}{*}{13} & Hall Ld & 55 & & shell & S-2408 & & 7825 & 130 & 7675 & England, 1985 \\
\hline & & & & replicate & GSC-3693 & & 7740 & 90 & 7590 & England, 1985 \\
\hline & & & & replicate & SI-6136 & & 7270 & 60 & $?$ & England, 1985 \\
\hline 13 & Hall Ld & 55 & 226446 & shell & I-9689 & & 8300 & 130 & 8150 & Weidick, 1978a \\
\hline $13 ?$ & Hall Ld & 12 & & shell & W-815 & & 3780 & 300 & 3230 & Rubin \& Alexander, 1960 \\
\hline 14 & Hall Ld & 110 & & shell & GSC-3744 & & 9580 & 140 & 9430 & England, 1985 \\
\hline
\end{tabular}




\begin{tabular}{lccccccc}
\hline Loc & Area & Height & Sample & Material & Lab. no. & & \multicolumn{3}{c}{ C-14 data } \\
no. & $\mathrm{m}$ & no. GGU & & & & & \\
\cline { 3 - 7 } & & & Delta & Lab. & 1 sigma & Reservoir \\
& & & C-13 & age & y & corrected \\
& & & $\%$ & y BP & & age y BP
\end{tabular}

\begin{tabular}{|c|c|c|c|c|c|c|c|c|c|c|}
\hline 15 & Hall Ld & 105 & & shell & S-2302 & & 8985 & 120 & 8835 & England, 1985 \\
\hline 15 & Hall Ld & 80 & 226440 & shell & $\mathrm{I}-9690$ & & 9005 & 145 & 8855 & Weidick, 1978a \\
\hline 15 & Hall Ld & 85 & 226441 & shell & I-9687 & & 9180 & 150 & 9030 & Weidick, 1978a \\
\hline $15 ?$ & Hall Ld & 82 & & shell & W-816 & & 6100 & 300 & 5550 & Rubin \& Alexander,1960 \\
\hline 16 & Hall Ld & 13 & & shell & S-2311 & & 4510 & 100 & 4360 & England, 1985 \\
\hline 18 & Nyeboe Ld & 59 & 313915 & shell & HAR-6294 & +1.9 & 8060 & 170 & 7510 & Kelly \& Bennike, 1985 \\
\hline 20 & Nyeboe Ld & 104 & 313863 & shell & HAR-6291 & +0.8 & 9060 & 100 & 8510 & Kelly \& Bennike, 1985 \\
\hline 20 & Nyeboe Ld & 13 & 313866 & shell & $\mathrm{K}-4376$ & -1.4 & 4640 & 90 & 4490 & Bennike \& Kelly, 1987 \\
\hline 21 & Nyeboe Ld & 87 & & shell & S-2308 & & 8745 & 150 & 8595 & England, 1985 \\
\hline 22 & Nyeboe Ld & 92 & & shell & S-2307 & & 9070 & 150 & 8920 & England, 1985 \\
\hline 23 & Nyeboe Ld & 28 & 313849 & shell & $\mathrm{K}-4375$ & +0.5 & 5530 & 95 & 5380 & Bennike \& Kelly, 1987 \\
\hline 25 & Nyeboe Ld & 80 & & shell & S-2309 & & 8205 & 135 & 8055 & England, 1985 \\
\hline & & & & replicate & SI-5856 & & 8230 & 85 & $?$ & England, 1985 \\
\hline 25 & Nyeboe Ld & 35 & & shell & GSC-3674 & & 6190 & 100 & 6040 & England, 1985 \\
\hline 31 & Nyeboe Ld & 87 & 313842 & shell & K-4339 & -1.0 & 10030 & 175 & 9880 & Kelly \& Bennike, 1985 \\
\hline 31 & Nyeboe Ld & 93 & 313841 & shell & HAR-6289 & +1.4 & 9390 & 90 & 8840 & Kelly \& Bennike, 1985 \\
\hline 32 & Nyeboe Ld & & 313935 & bone & Ua-323 & & 2155 & 90 & & Bennike \& Kelly, 1987 \\
\hline 34 & Nyeboe Ld & 24 & 313940 & shell & K-4380 & +2.3 & 4870 & 80 & 4720 & Bennike \& Kelly, 1987 \\
\hline 36 & Warming Ld & 69 & 313948 & shell & HAR-6290 & +1.3 & 8210 & 120 & 7660 & Kelly \& Bennike, 1985 \\
\hline 37 & Warming Ld & 115 & 313944 & wood & Ua-948 & & $>40000$ & & & This work \\
\hline 37 & Warming Ld & 115 & 313944 & $\begin{array}{r}\text { plant } \\
\text { detritus }\end{array}$ & $\mathrm{K}-4574$ & -27.5 & 32270 & $\begin{array}{r}+1120 \\
-1200\end{array}$ & & Bennike \& Kelly, 1987 \\
\hline 40 & Warming Ld & 26 & 313801 & shell & HAR-6287 & +2.3 & 6480 & 100 & 5930 & Kelly \& Bennike, 1985 \\
\hline 41 & Wulff Ld & 275 & 313804 & peat & $\mathrm{K}-4573$ & -25.2 & 5100 & 130 & & Bennike \& Kelly, 1987 \\
\hline 42 & Wulff Ld & 28 & 313814 & shell & K-4373 & +0.2 & 6780 & 105 & 6630 & Bennike \& Kelly, 1987 \\
\hline 43 & Wulff $\mathrm{Ld}$ & 72 & 313813 & algae & GU-2588 & -23.4 & 10480 & 90 & & This work \\
\hline 44 & Wulff Ld & 62 & 313833 & shell & $\mathrm{K}-4374$ & +1.8 & 8000 & 115 & 7850 & Bennike \& Kelly, 1987 \\
\hline 45 & Wulff Ld & 5 & 313949 & shell & K-4381 & +0.1 & 5180 & 90 & 5030 & Bennike \& Kelly, 1987 \\
\hline 47 & Peary Ld & $30-35$ & 226451 & shell & I-9664 & & 5700 & 105 & 5550 & Weidick, 1978a \\
\hline 47 & Peary Ld & & 215308 & shell & GSC-2279 & & 4190 & 140 & 4040 & Weidick, $1977 \mathrm{~b}$ \\
\hline 47 & Peary Ld & & 215308 & wood & I-9130 & & $<220$ & & & Weidick, $1977 \mathrm{~b}$ \\
\hline 48 & Nansen Ld & 11 & 313932 & shell & HAR-6746 & +1.7 & 6100 & 100 & 5550 & Bennike \& Kelly, 1987 \\
\hline 53 & Nansen Ld & 71 & 313930 & shell & Ua-260 & & 9700 & 100 & 9150 & Bennike \& Kelly, 1987 \\
\hline 54 & Nansen Ld & 41 & 313828 & shell & HAR-6288 & +1.7 & 7980 & 120 & 7430 & Kelly \& Bennike, 1985 \\
\hline
\end{tabular}


the area were recognised first by Koch (1928a, b), i.e. that there was evidence of two stages of glaciation, an early complete coverage of the area by the Greenland ice sheet, except for Nansen Land - which was covered by an ice cap - and a later more limited advance of fjord glaciers from the ice sheet, which laid down lateral moraines on either side of Hall Land and dammed up a glacial lake between them. The subsequent work has attempted to refine this stratigraphy and define and date the number and extent of glacial advances and related marine incursions. Despite the application of modern dating techniques there is still controversy about these, in particular concerning the events of the Last Glaciation (England, 1985, 1987; Dawes, 1987; Bennike et al., 1987).

\section{Methods}

During the fieldwork, logistic support was provided by helicopters and a fixed wing aircraft, enabling data to be collected from about 600 ground localities. The field information was obtained by mapping of surface deposits and features, together with a limited amount of excavation and description of profiles. Altitudes in the field were determined with a Paulin aneroid altimeter which was checked at least twice a day against the approximate mean sea level, or with fixed survey points which had been related to sea level. The errors were distributed linearly over the intervening periods. The residual error on the reported altitudes is considered to be \pm 5 $\mathrm{m}$. All altitudes given are in metres above sea level. The area visited in the field corresponds to only about $3-4 \%$ of the land area (Map 1). However, the field data have been extended by the geological interpretation of 1:150 000 scale vertical aerial photographs over most of the area.

In addition, an analytical programme has provided 31 radiocarbon dates and amino acid analyses for 4 samples. The radiocarbon analyses were carried out by conventional methods at the laboratories at Copenhagen, Denmark; Harwell and Glasgow, U. K., and by accelerator mass spectrometry at the laboratory at Uppsala, Sweden. Details of those dates not already published in Kelly \& Bennike (1985) and Bennike \& Kelly (1987) are given in Appendix 1. All the radiocarbon dates obtained from western and central North Greenland, including those by other investigators, are compiled in Table 1 and the sample localities are shown in Fig. 1. For this purpose, dates on marine shell material produced by different laboratories have been brought to a standard basis, if the original laboratory practice is known, i.e. corrected for isotopic fractionation by normalisation to $-25 \mathrm{ppt} \delta^{13} \mathrm{C}$, and corrected for oceanic reservoir effects, by using an apparent age of 550 years for the Arctic Ocean, as proposed by Funder (1982). The corrections used, according to laboratory code, are: GSC, I, K, S: -150 a; HAR, Ua, W: -550 a. These corrections are approximate for laboratories which have not measured the $\delta^{13} \mathrm{C}$ value but, at that time, either assumed it to be equal to zero or ignored carbon isotope fractionation effects ( $\mathrm{K}$ (pre K-2455), I, S, Ua, W). The amino acid analyses were carried out by the Geochronology Laboratory, University of Colarado, and the results are given in Table 2 and the localities in Fig. 1.

Table 2. Amino acid analyses of Hiatella arctica shell fragments, western and central North Greenland

\begin{tabular}{|c|c|c|c|c|c|c|}
\hline \multirow[t]{2}{*}{$\begin{array}{l}\text { Locality } \\
\text { no. }\end{array}$} & \multirow[t]{2}{*}{ Area } & \multirow{2}{*}{$\begin{array}{l}\text { Height } \\
\text { m above } \\
\text { sea level }\end{array}$} & \multirow{2}{*}{$\begin{array}{c}\text { Sample } \\
\text { no. } \\
\text { GGU- }\end{array}$} & \multirow{2}{*}{$\begin{array}{c}\text { Lab. } \\
\text { no. } \\
\text { AAL- }\end{array}$} & \multicolumn{2}{|c|}{$\begin{array}{c}\text { Alloisoleucine/isoleucine } \\
\text { Alle/lle }\end{array}$} \\
\hline & & & & & Total & Free \\
\hline 7 & Hall Ld & 139 & 313892 & $\begin{array}{c}4521 \mathrm{~A} \\
\mathrm{~B} \\
\mathrm{C}\end{array}$ & $\begin{array}{l}0.062 \\
0.080 \\
0.088\end{array}$ & $\begin{array}{l}0.33 \\
0.33 \\
0.33\end{array}$ \\
\hline 9 & Hall Ld & 352 & 313913 & $\begin{array}{c}4522 \mathrm{~A} \\
\mathrm{~B} \\
\mathrm{C}\end{array}$ & $\begin{array}{l}0.035 \\
0.050 \\
0.056\end{array}$ & $\begin{array}{l}0.11 \\
0.18 \\
0.20\end{array}$ \\
\hline 12 & Hall Ld & 227 & 313858 & $\begin{array}{c}4520 A \\
\text { B } \\
\text { C } \\
\text { D }\end{array}$ & $\begin{array}{l}0.044 \\
0.040 \\
0.042 \\
0.047\end{array}$ & $\begin{array}{l}0.20 \\
0.16 \\
0.23 \\
\text { low }\end{array}$ \\
\hline 37 & Warming Ld & 115 & 313945 & $\begin{array}{c}4523 \mathrm{~A} \\
\mathrm{~B} \\
\mathrm{C}\end{array}$ & $\begin{array}{l}0.048 \\
0.062 \\
0.077\end{array}$ & $\begin{array}{l}0.23 \\
0.35 \\
0.32\end{array}$ \\
\hline
\end{tabular}




\section{Stratigraphy}

The distribution of Quaternary deposits and significant landforms in western and central North Greenland is shown on the accompanying 1:1 million map (Map 1). The geochronological data for the region are shown in Tables 1 \& 2 .

The Quaternary geology of the area indicates that it has experienced a complex history of glacial advances and periods of marine inundation. Five glacial stades and two marine events are proposed on the basis of the degree of preservation of landforms and deposits, their topographic relationships and the spatial relationships of marine and glacial deposits. These events have been dated, as far as possible, from the geochronological data and by correlation with elsewhere. This stratigraphy is summarised in Fig. 2, and the supporting evidence is considered in the following sections.

\section{Kap Bryant stade (Saalian?)}

The earliest known event is the Kap Bryant stade, during which there was a major advance of the Greenland ice sheet over most of the present land and onto the continental shelf, where an ice shelf was probably created. The evidence indicates that this is a relatively old event, and the Saalian age is suggested by correlation with elsewhere in Greenland.

The stade is represented today by till deposits and isolated erratics in the northern parts of the peninsulas of Hall Land, Nyeboe Land, Wulff Land, and Nares Land adjacent to the Arctic Ocean. The tills, consisting largely of thin soliflucted deposits, are present on low angle slopes facing the Arctic Ocean, as in Nyeboe Land, and on broad upland surfaces in the interior of the peninsulas up to about $400 \mathrm{~m}$ above sea level. Generally, depositional features are absent in these areas and exposed till clasts and erratics have a relatively weathered appearance. The distribution of isolated erratics extends up to the summits of the hills along the north coast (Fig. 3), e.g. gneiss erratics occur at elevations of $840 \mathrm{~m}$ above sea level on Hall Land, $869 \mathrm{~m}$ on Nyeboe Land, $867 \mathrm{~m}$ on Wulff Land, and Koch (1928a) records limestone erratics from 'about 1000 m' on Hendrik $\emptyset$.

The till clasts and erratics, whilst mainly varieties of sandstones and limestones, include gneissose and granitic rocks. The frequency of these crystalline rocks is greatest in the south-west where they derive from outcrops of Precambrian rocks which are mainly beneath the Inland Ice. Their occurrence is clear evidence that the glaciation of this stade was the result of an ice sheet advancing over the area from the south, as has been recognised by previous authors (Koch, 1928a, b; Davies et al., 1959; Davies, 1972; Dawes, 1987). The high level occurrence of erratics indicates that the ice sheet extended at least $20 \mathrm{~km}$ onto the shelf.

The stade has been named after the Kap Bryant area of north-east Nyeboe Land, where the relationship between its deposits and those of the younger Kap Fulford stade are clearly seen (Fig. 4). The only evidence as to the age of the Kap Bryant stade is that the more weathered aspect of the terrain and degraded depositional landforms suggest that a long time gap separates it from the Kap Fulford stade described below. This places it in the Saalian or Early Weichselian, and, on the evidence of the correlation with other parts of Greenland, the earlier age is preferred.

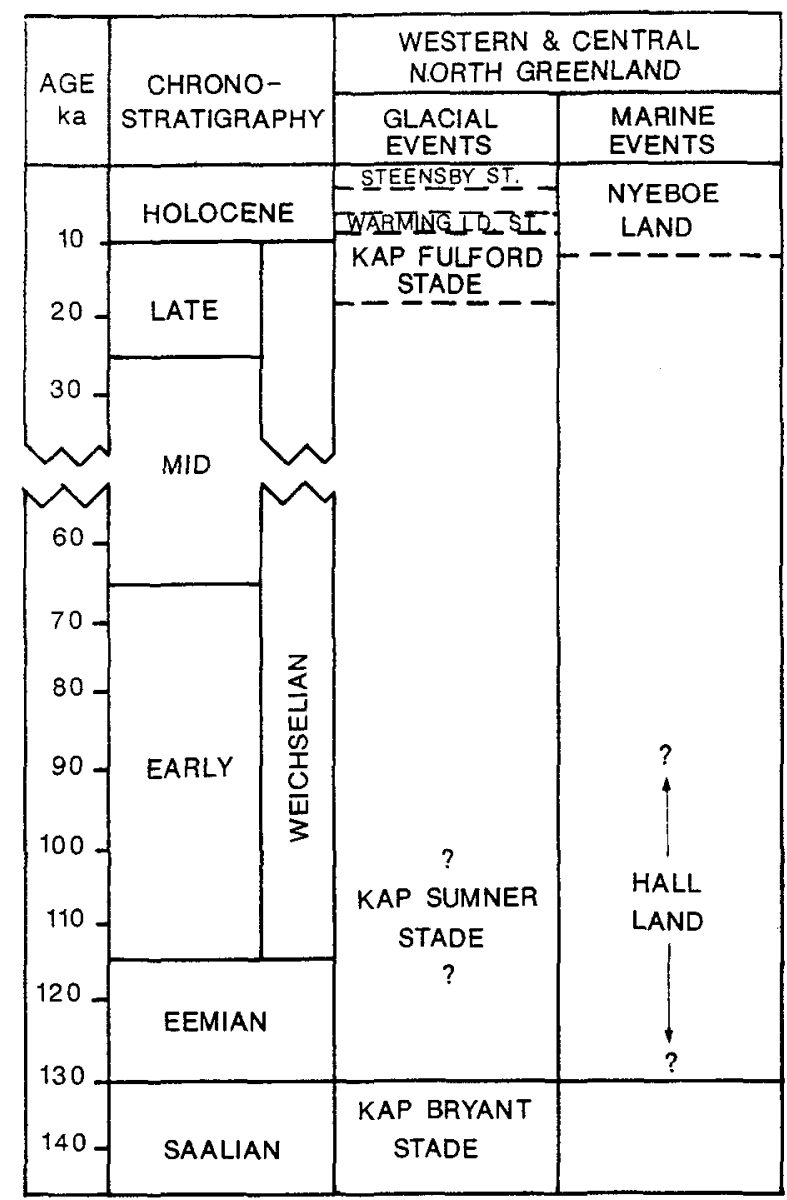

Fig. 2. Proposed model of Late Quaternary stratigraphy of western and central North Greenland. 


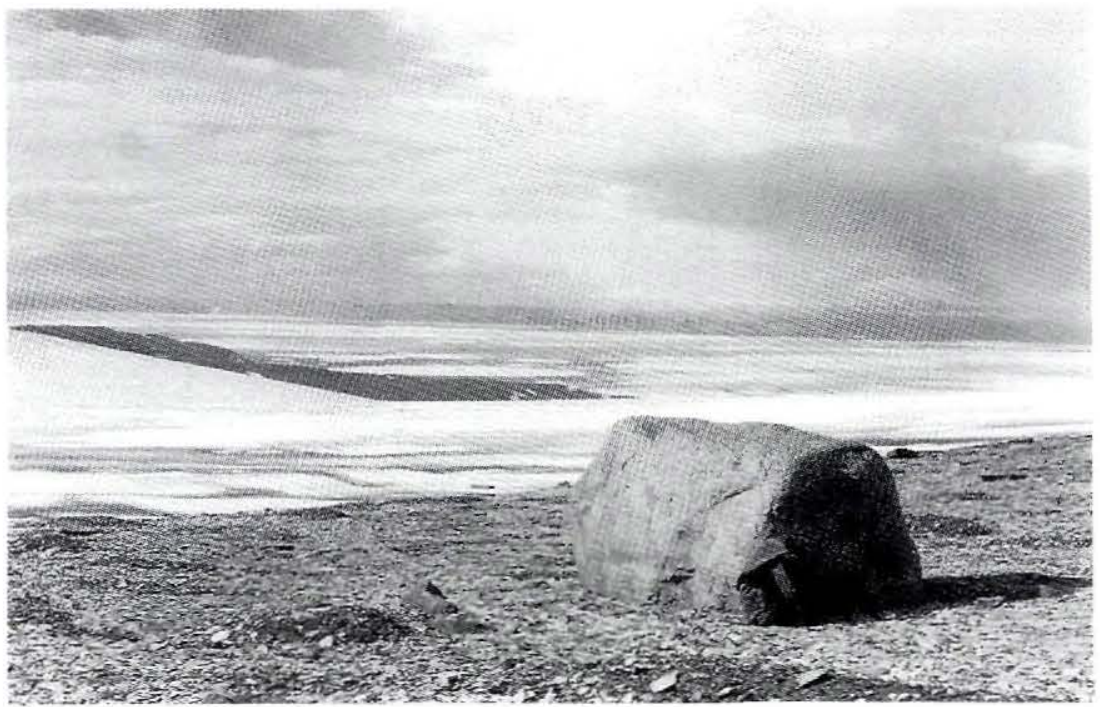

Fig. 3. Granitic gneiss erratic on frost shattered bedrock on summit $(869 \mathrm{~m})$ overlooking Nares Strait and Ellesmere Island. Nyeboe Land.

It is not certain what the conditions in this stade were in the outer part of Nansen Land, as it was not investigated in any detail. However, its distinctive topography, with a dendritic pattern of V-shaped valleys, has long suggested that it has had a different glaciation history to the rest of the area (Koch, 1928a). Glacial tills are present on the lower slopes along the Arctic Ocean coast at least up to $150 \mathrm{~m}$ above sea level, e.g. along Gardiner Fjord, Jewell Fjord and Lemming Fjord, as well as in the major valley system at Th. Thomsen Fjord. The clasts in these are almost exclusively without obvious exotic erratics. The exceptions are rare granitic

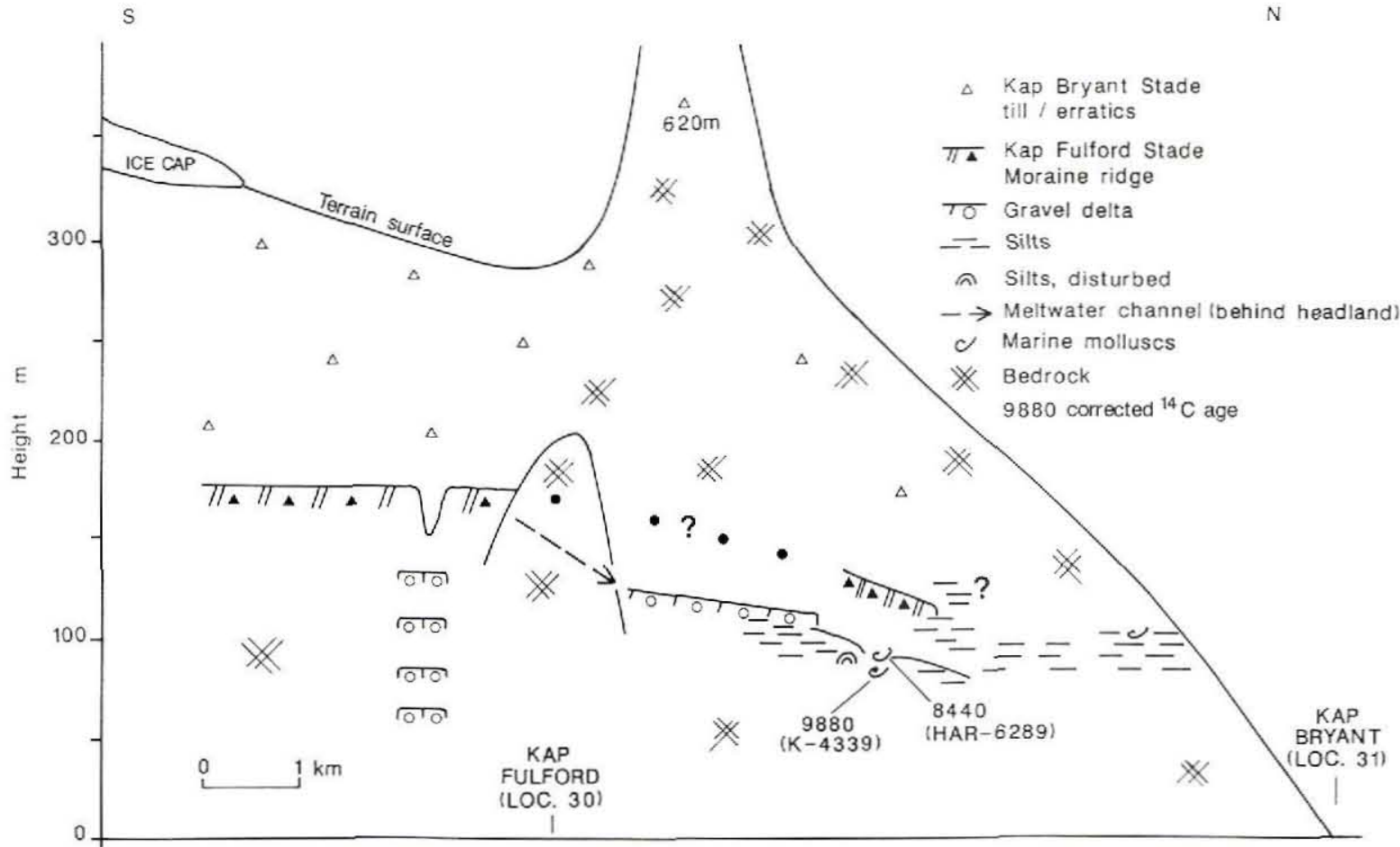

Fig. 4. Digarammatic view of western side of Sankt George Fjord (Kap Fulford and Kap Bryant) showing the distribution of features and surface deposits. 
gneiss erratics seen at two localities below the Holocene marine limit along the north coast, at Low Point and 'Pocket Bay' (Fig. 1, loc. 52). The age of these tills is uncertain but, since well preserved glacial depositional features are absent, they are correlated with the Kap Bryant stade. It is also unclear whether they were deposited by local glaciers or by the main ice sheet. Erratics on a summit at $765 \mathrm{~m}$ above sea level at the southeast edge of the upland area of outer Nansen Land indicate that in this stade the southern ice sheet extended over at least part of the area. It may have been confluent with a local ice cap or it may have extended over the area to or beyond the outer coast. The occurrence of crystalline erratics along the adjacent north coast of Peary Land has been interpreted by Dawes (1986) as evidence of transport from a source area in the west by an active ice shelf rather than by Holocene iceberg rafting, since the present oceanic circulation is from the opposite direction. His reconstruction of the ice margin is compatible with that of the Kap Bryant stade.

It is most likely that the unique landscape is the combined product of the weak rock types (folded, partly metamorphosed Cambrian trough facies), which occur in this area, and the prolonged period of weathering due to the lack of any significant ice cover since the Kap Bryant stade.

\section{Hall Land marine event (Eemian - Early Weichselian?)}

The Hall Land marine event is poorly defined and is known primarily from reworked marine shells contained in tills of younger glacial events, although in situ deposits may occur in Hall Land. By correlation of amino acid parameters with data from other parts of Greenland, an Eemian to Early Weichselian age is suggested for the original event.

The shell-bearing tills (of Kap Sumner and Kap Fulford stade age) are fairly frequent in parts of Hall Land and Nyeboe Land adjacent to the fjord systems, where they can be found up to elevations of $384 \mathrm{~m}$ on northwest Hall Land and $240 \mathrm{~m}$ on north-west Nyeboe Land. Two sites in Hall Land have given non-finite ${ }^{14} \mathrm{C}$ dates and the amino acid data for them, and for samples from two other sites, also indicate pre-Holocene ages (Tables $1 \& 2$ ). Both the total and free alloisoleucine/isoleucine (aIle/Ile) ratios show a wide range of values, both within as well as between samples. Part of this spread could be due to different diagenetic temperatures experienced by the shell fragments during glacial reworking and subsequent depositon and erosion. It is unclear, therefore, whether more than one marine event is represented by these values. Hence, only one event is provisionally proposed: the Hall Land marine event, corresponding to the Hall Land aminozone, i.e. with total alle/Ile ratios of $0.035-0.088$ and free ratios of $0.11-0.35$. These ratios indicate a pre-Holocene age for the event and they can be correlated with aminozones referred to the Eemian and early Weichselian from north-west and west Greenland (Kelly, 1985; Funder, 1990) (see section on correlation).

England (1985) has described two localities in Hall Land where deposits of pre-Holocene marine sediments are preserved. These have mollusc faunas with nonfinite ${ }^{14} \mathrm{C}$ ages ( $>33 \mathrm{ka}$ ). At one of the sites, abundant Hiatella arctica shells are described as being "in growth position in littoral sands" at $142 \mathrm{~m}$ above sea level. At the other locality, the shells are redeposited single or fragmented valves of $H$. arctica in a glacio-marine silt at $132 \mathrm{~m}$ above sea level (England, 1985). These two occurrences play a critical part in his interpretation of the stratigraphy of the area, which is discussed later. In the absence of amino acid determinations, these deposits can be correlated only tentatively with the reworked faunas in the tills and only provisionally assigned to the Hall Land marine event.

\section{Kap Sumner stade (Early Weichselian?)}

The Kap Sumner stade - the least well known glacial event - is considered to have been a period of advance of the ice sheet which brought its glacier lobes to the mouths of fjords and interior valleys, forming lateral moraine systems. This is provisionally dated to the Early Weichselian.

In north-east Hall Land, at Kap Sumner, large degraded moraines, containing reworked marine shell fragments and crystalline erratics, lie just outside moraines assigned to the younger Kap Fulford stade. Also, in the valley in central Nyeboe Land running north to Frankfield Bugt, aerial photographs show degraded moraine systems delineating a lobe of ice from the ice sheet, which extends $20 \mathrm{~km}$ beyond the Kap Fulford stade moraines. At Kap Sumner, the deposits are distinguished from those of the Kap Bryant stade by their shell content and better morphology, and from the Kap Fulford stade by the degree of morphological degradation, and they are considered to belong to a separate advance of the ice sheet and its outlet lobes. The reworked shells, although undated, are presumed to derive from the Hall Land marine event. The age of the Kap Sumner stade, therefore should lie between the Hall Land marine (at least in part) and Kap Fulford stade glacial events. By analogy with other parts of 
Greenland (see section on correlation), it is provisionally given an early Weichselian age. However, the identity and age of this stade are less well known than for other stades and further work is needed to confirm its reality.

\section{Non-glacial terrestrial facies (Weichselian)}

Thick, periglacially produced regoliths are important in areas of bedrock outcrop not glaciated since the Kap Bryant stade. The summits and steep slopes of the hills in the northern parts of Hall Land, Nyeboe Land, Wulff and and Nares Land are covered with boulder fields of local bedrock over $1.5 \mathrm{~m}$ thick. In addition, on the plateaux of Nyeboe Land there is a silt rich deposit, > $0.5 \mathrm{~m}$ thick, with occasional erratics and a surface veneer of erratic gravel. This is thought to be largely of autochthonous origin, derived from the periglacial weathering of the mudstones of the Middle and Upper Silurian turbidite facies. During the summer thaw of the active layer, this deposit is very susceptible to shallow mudflow failure. These regoliths are presumed to have developed over the long period of cold climate in the Weichselian.

Non-glacial sediments, of presumed Eemian or Weichselian age, are known from Warming Land. There, the Skalhøjene unit consists of laminated sands and silts with organic laminae which give non-finite ${ }^{14} \mathrm{C}$ ages (Table 1). These sediments underlie a till of Kap Fulford stade and/or Warming Land stade age. The organic remains (see section on biota) indicate that climatic conditions were similar to the present and the sediments are thought to have been deposited in a lake (Meldgaard \& Bennike, 1989).

\section{Kap Fulford stade (Late Weichselian)}

In the Kap Fulford stade, an ice sheet advanced over the southern half of the region and its outlet glaciers extended down the major fjords to their mouths, where their termini would have been floating. The Kap Fulford Stade ice advanced over the Hall Land marine event deposits which are postulated to be Eemian or Early Weichselian in age. The relatively fresh appearance of the Kap Fulford stade deposits and landforms indicates a considerable age difference between this stade and the Kap Bryant stade. A Late Weichselian age is suggested because, in the key areas, its early retreat history appears to be linked to the period of glacio-isostatic emergence marked by the Nyeboe Land marine event of end Weichselian-Holocene age.

The relationships of the deposits of this stade to other stratigraphic units are best seen at Kap Fulford, in north-east Nyeboe Land, after which the stade is named. There, lateral moraines along the western side of Sankt George Fjord extend down from $200 \mathrm{~m}$ above sea level (Fig. 5). The exotic erratic content, which includes gneisses, indicates that these moraines were built by outlet glaciers from an ice sheet advancing from the south (Fig. 4). The outermost moraine terminates at $114 \mathrm{~m}$ above sea level, where it overlies silts. Inside this, a marginal drainage channel related to a well developed lateral moraine leads to a large gravel kame which is built over thick silts and which extends down to an altitude of $113 \mathrm{~m}$. These silts are without macrofossils

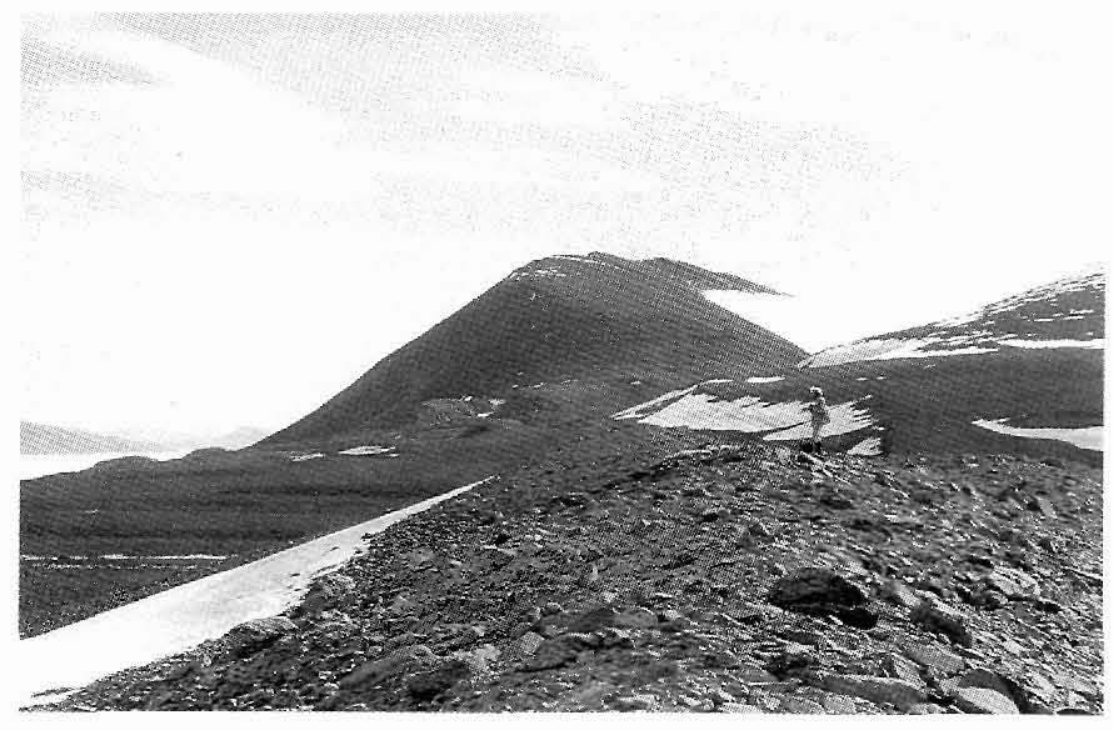

Fig. 5. Kap Fulford moraine looking south, Nyeboe Land. 
but are considered, from their topographic position facing the Arctic Ocean, to be marine. Unfossiliferous silts also occur above the moraine in a small side valley up to 119-127 $\mathrm{m}$ above sea level but may be glacio-lacustrine. An outcrop of silts and sands in front of the gravel kame contains marine fossils up to $92 \mathrm{~m}$ above sea level which have Early Holocene ${ }^{14} \mathrm{C}$ ages (8.8 and $9.9 \mathrm{ka}$ ).

The Kap Fulford stade moraines mark the maximum position reached by an outlet glacier from the Greenland ice sheet, at a time when sea levels were at about $114 \mathrm{~m}$ above sea level. The age suggested for this event depends on the interpretation of the relationship between the undated pre-Kap Fulford stade unfossiliferous sediments and the dated, younger, Nyeboe Land marine event sediments. The simplest interpretation is favoured - that both sets of sediments belong to the same marine interval. This interpretation would place the oldest dated marine faunas in the period of initial retreat of the Kap Fulford glacier and date the maximum advance to the end of the Late Weichselian.

Other evidence of the age of the Kap Fulford stade comes from Wulff Land where a lobe of the ice sheet reached down the valley in the middle of the peninsula to a terminal position at the north coast marked by poorly developed marginal features which extend down to $114 \mathrm{~m}$ above sea level. Nearby, silts without macrofossils but presumed to be of marine origin, occur at elevations up to $116 \mathrm{~m}$, whilst the highest Holocene fossiliferous sediments are at an altitude of $85 \mathrm{~m}$. Ten kilometres up valley from the coast, at $72 \mathrm{~m}$ above sea level, a lens of freshwater organic silt between local alluvial fan sediments and underlying erratic rich outwash gravels and diamictons gives a minimum date of $10.5 \mathrm{ka}$ for the retreat of the Kap Fulford stade.

In the central part of the area, lateral moraines and marginal drainage channels from the main phase of the Kap Fulford stade can be traced along the fjord sides to the south, where they rise to about $600 \mathrm{~m}$ above sea level. Further south, the ice coalesced and the ice sheet covered the interior plateaux of the southern ends of the peninsulas, laying down the erratic rich tills which occur there. In valleys on Nares Land an extensive series of glacial lakes were dammed by ice in Nordenskiöld Fjord. These are marked by benches up to $240 \mathrm{~m}$ above sea level which sharply define the lower limit of boulder fields on adjacent slopes.

In the east, on Nansen Land, the ice seems to have been relatively less extensive. On the north side of outer J. P. Koch Fjord lateral ice marginal features extend up to $360 \mathrm{~m}$ above sea level. This is low, if they represent the upper limit of ice with its terminus in the region of Murray $\emptyset$, and the glacier must have been floating. Tongues from the fjord glacier penetrated the inlets on the north side as well as the major valleys, showing that they were not occupied by local valley glaciers at that time. Again, the presence of gneiss erratics indicates that this glacier was fed by the main ice sheet. In northeast Nansen Land, the margins of this stage are not well defined. Although the large ice cap at the head of the fjord system, Hans Tavsen Iskappe, would have been incorporated in the Greenland ice sheet, the advance in this area was seemingly limited. The highest ice marginal features at the southern end of Brainard Sund, at 500 $m$ above sea level, may date from the maximum of the advance or may be a retreat stage. A large delta at an altitude of $94 \mathrm{~m}$ at the head of Th. Thomsen Fjord, which marks the marine limit, may have been constructed from outwash from this stage, fed from a lobe of the ice sheet penetrating down the valley from the south-east.

In the western part of the area, in Hall Land and north-west Nyeboe Land, lightly weathered and well preserved shell bearing moraines occur at the northern ends of Robeson Channel and Newman Bugt (e.g. at Kap Ammen and Kap Sumner). They are dated to the Kap Fulford stade because of their similar morphology and lithology, and because they indicate a similar degree of expansion for the Greenland ice sheet in the western sector as further east. However, although the moraines evidently pre-date the early Holocene and post-date the Hall Land marine event, their stratigraphical relationship to the Nyeboe Land marine event is less clear in Hall Land than elsewhere, and different stratigraphic interpretations have been made by others (e.g. England, 1985, 1987; Dawes, 1987) (see the section on alternative models).

At Kap Sumner on Hall Land, the lateral moraines mapped previously by Davies (1972) and Dawes (1977, 1987), have a fresh morphology and lie inside the degraded moraines of the Kap Sumner stade, at 280-213 $\mathrm{m}$ above sea level. Fragments of reworked shells in the moraines gave non-finite ${ }^{14} \mathrm{C}$ ages and old amino acid values (Table 2). Extensive outwash deposits of silts, sands and gravels were deposited up to elevations of $\mathbf{1 7 2}$ $m$ in the valley to the north, when this was dammed up by the ice in the fjord. The upper terrace of the delta at the valley mouth, at $135 \mathrm{~m}$ above sea level, could be related to either ice or sea levels. The highest marine faunas found in the delta deposits, presumably of Nyeboe Land marine event age, were at an altitude of $65 \mathrm{~m}$.

Corresponding depositional features are absent on the east side of Newman Bugt where, instead, there is a remarkable series of deep marginal drainage channels which belong to this stade, at least in part. The channels, running parallel to the fjord side, are up to $60 \mathrm{~m}$ deep, cut in the soft Silurian mudstone bedrock and 


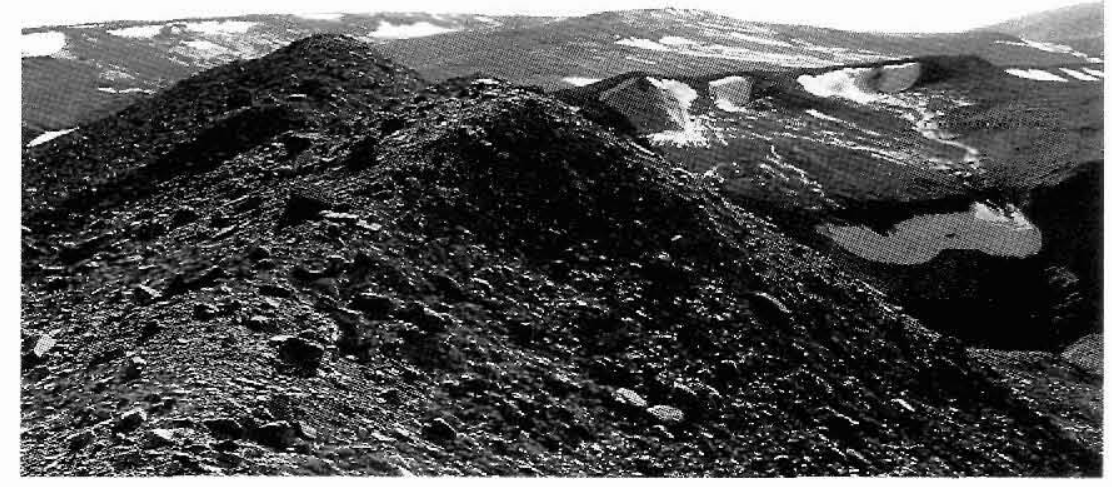

Fig. 6. Kap Ammen moraine (Hall Land) looking south-west. with the proximal side facing Nares Strait to the right.

have thresholds at altitudes of $100-190 \mathrm{~m}$ above sea level. They appear to have been partially re-excavated from an older series which can be seen as a totally sediment choked channel at one locality.

Further to the west is the moraine at Kap Ammen first mapped by Dawes $(1977,1987)$. It is a $30 \mathrm{~m}$ high, lightly weathered, sharp-crested terminal moraine lying, at $275 \mathrm{~m}$ above sea level, on the edge of the plateau around the head of a valley up which the ice advanced from Robeson Channel (Fig. 6). Its continuation can be traced on the west side as a lateral moraine rising to the north, i.e. down valley, to end at the top of the cliffs overlooking Robeson Channel at $540 \mathrm{~m}$ above sea level. These moraines are rich in erratics, especially carbonate rocks of various lithologies, together with small percentages of chert, sandstones and gneisses. The carbonate rocks are likely to have been derived largely from the Silurian and Ordovician shelf facies outcrops in the Robeson Channel cliffs. The gneisses, however, show that the ice derived from the main ice sheet. These features clearly indicate the presence of a considerable thickness of ice in the Robeson Channel. Further west, the ice margin can be traced as a boundary between a carbonate erratic rich till and a more heavily soliflucted and weathered till on the plateau edge at about $380 \mathrm{~m}$ above sea level. In the valley below the Kap Ammen moraine fossiliferous Holocene marine sediments occur up to elevations of at least $76 \mathrm{~m}$. Along the coast of north-west Nyeboe Land, facing the Arctic Ocean, are areas of erratic rich tills at low elevations (e.g. Drift Point at $171 \mathrm{~m}$ above sea level) which may be related to the seaward extension of the Kap Ammen lobe.

\section{Nyeboe Land marine event (end Weichselian - Holocene)}

The Nyeboe Land marine event begins during the transgression associated with the Kap Fulford stade advance and covers the subsequent period of regression and isostatic recovery following its retreat. Whilst largely dating from the Holocene, the earliest deposits and features probably date from the end of the Weichselian. Thus, the features proposed as marking the marine limit of this event are, typically, $20-30 \mathrm{~m}$ above the highest Holocene faunas.

\section{Distribution and marine limit}

Marine sediments with shell faunas giving Holocene ${ }^{14} \mathrm{C}$ dates clearly belong to this event. The largest occurrence of these sediments is in central Hall Land where they form a discontinuous belt across the peninsula. Elsewhere, they are distributed along the margins of fjords and the outer coast (Map 1). Lithologically, they include shallow and deep water marine sands and muds, glacio-marine diamictons and littoral gravels. Diamictons may include submarine debris flow deposits but are mainly sorted sediments rich in clasts representing deposition from floating ice. Dropstones exist in all facies but an important contrast exists between fine sediments which are clast poor and those which are clast rich.

The vertical distribution of deposits of this event is difficult to assess, because of possible confusion between glacio-lacustrine and marine shorelines, and also between their sediments, if unfossiliferous. This complication, and the general lack of well marked wash limits 


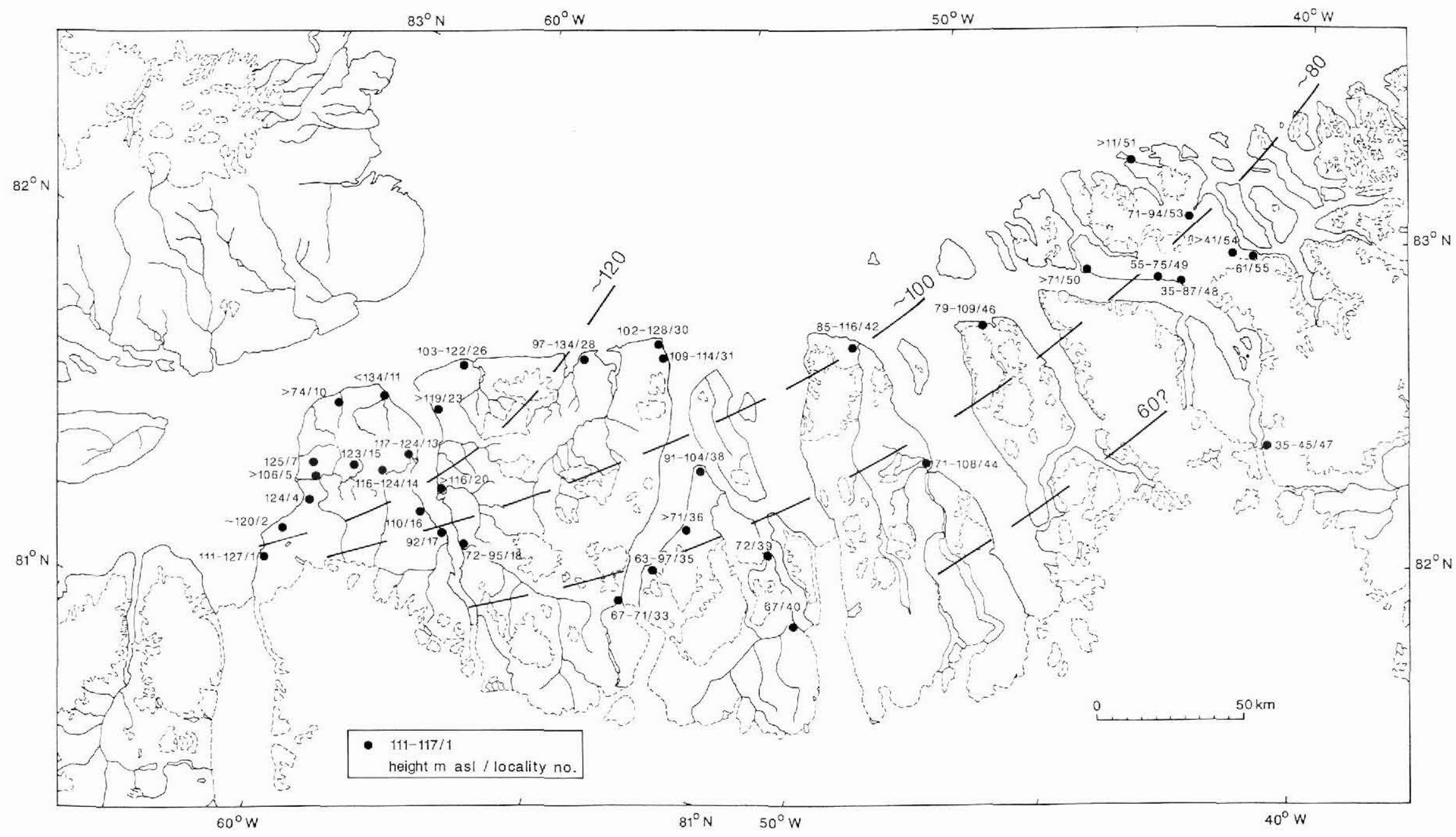

Fig. 7. Height of limit of Nycboe Land marine event transgression (Late Weichsclian - Holocene) (see Appendix 3 for locality details). 
or perched boulder limits, makes the definition of the limit of marine transgression - the marine limit - for the Nyeboe Land event difficult. Figure 7 shows the distribution of the altitudes of the marine limit and the supporting evidence is summarised in Appendix 3.

The highest marine limits found were at altitudes around $125 \mathrm{~m}$ in central Hall Land and $114 \mathrm{~m}$ in northeast Nyeboe Land. Its height in northern Hall Land, where it might be expected to be highest according to our stratigraphical model, could not be determined for lack of evidence. These elevations indicate the existence of considerable isostatic depression over the north-west part of the region in the Late Weichselian. Such an amount of emergence, over $100 \mathrm{~m}$, is known from only two other parts of Greenland - in the coastal region of central West Greenland close to the position of the margin of the Late Weichselian Sisimiut ice sheet which reached to the inner shelf (Kelly, 1985), and from the inner part of Scoresby Sund, close to the marginal position of the end Weichselian - early Holocene ice sheet of the Milne Land stade (Funder, 1978; Funder et al., 1989). It is considered significant that, in all three cases, this amount of emergence is associated with the marginal zone of a major ice sheet advance. The fall in the height of the marine limit towards the north-east is compatible with a reduced ice load in this area, as a consequence of the more limited expansion of the main ice sheet and the possible development of a local ice cover over Nansen Land (see below). The decrease in marine limit height towards the south-east reflects the increasing proportion of the isostatic recovery that has occurred before deglaciation during the progressive retreat of the ice sheet margin.

The heights of the marine limit in the western part of the region differ from those proposed by England (1985), e.g. in central Hall Land, where he places it at $150 \mathrm{~m}$ above sea level. In this area, however, there are extensive deposits and features related to the development of a glacial lake in the central lowland, where shoreline features and deposits occur up to $235 \mathrm{~m}$ above sea level making identification of the marine limit difficult. It is proposed that a better estimate of its height is $125 \mathrm{~m}$ above sea level. This is close to England's height for the marine limit on the proximal side of the Polaris Bugt moraine. In our interpretation, this moraine predates the marine limit. It also agrees with Dawes' estimate of the altitude of the limit in the area (Dawes, 1987). The marine limits on either side of Newman Bugt are also put about $20 \mathrm{~m}$ lower than by England (1985).

\section{Sea level change and emergence}

Although there is insufficient data to precisely define an emergence curve for a particular locality, the large number of ${ }^{14} \mathrm{C}$ dates for Hall Land and western Nyeboe Land allow the general trend of sea level change in the Nyeboe Land marine event to be inferred (Fig. 7). The data for this area of about $25 \mathrm{~km}$ radius are mainly mollusc shell dates taken from Rubin \& Alexander (1960); Weidick (1977b, 1978a); England (1985); Kelly \& Bennike (1985 \& this paper); Bennike \& Kelly (1987). In addition, a date on musk-ox bone from an Independence I palaeo-Eskimo site on a beach ridge is included (Knuth, 1981).

At least one of the critical dates for the construction of an emergence curve for the area is suspect. The date of $5.6 \mathrm{ka}$ for marine shells from $82 \mathrm{~m}$ above sea level from central Hall Land (Davies in Rubin \& Alexander, 1960) was an important datum in the early stratigraphic schemes for the area, being taken to indicate a midHolocene age for the readvance of fjord glaciers (implied in Davies, 1963; Weidick, 1972, 1975), but the date has subsequently been questioned by Weidick (1978b). We consider that not only is the interpretation of the relationship of the dated marine deposits to those of the fjord glacier wrong but the date or height is also erroneous.

The emergence curve based on the remaining evidence (Fig. 8) suggests that there was an initial period of about $2 \mathrm{ka}$ when emergence slowly accelerated. This is somewhat anomalous, since according to our stratigraphic model, considerable deglaciation should have occurred from the maximum position of the Kap Fulford stade by the time the marine limit was formed in central Hall Land (about 9.5-10.0 ka), and rapid uplift would be expected. One possible explanation is that there is an unknown source of error in the two critical dates $(7.2 \&$ $7.5 \mathrm{ka}$ at $102 \& 105 \mathrm{~m}$ above sea level). These are both from shells from the top of the Polaris Bugt moraine, collected and analysed independently by ourselves and England (1985). Alternatively, the curve may reflect a period of stability or readvance of the ice margin around $8-9 \mathrm{ka}$, i.e. in the Warming Land stade, for which there is some evidence (see below).

In general, emergence curves from the Greenland Holocene (Kelly, 1985; Funder, 1989) show a period of rapid uplift after the formation of the marine limit, although Bennike (1987) has described a similar initial period of slow emergence from Jørgen Brønlund Fjord in eastern North Greenland. England $(1983,1985)$ has provided a completely different explanation of the data, suggesting that the early phase of emergence in the Holocene in Hall Land and north-eastern Ellesmere 


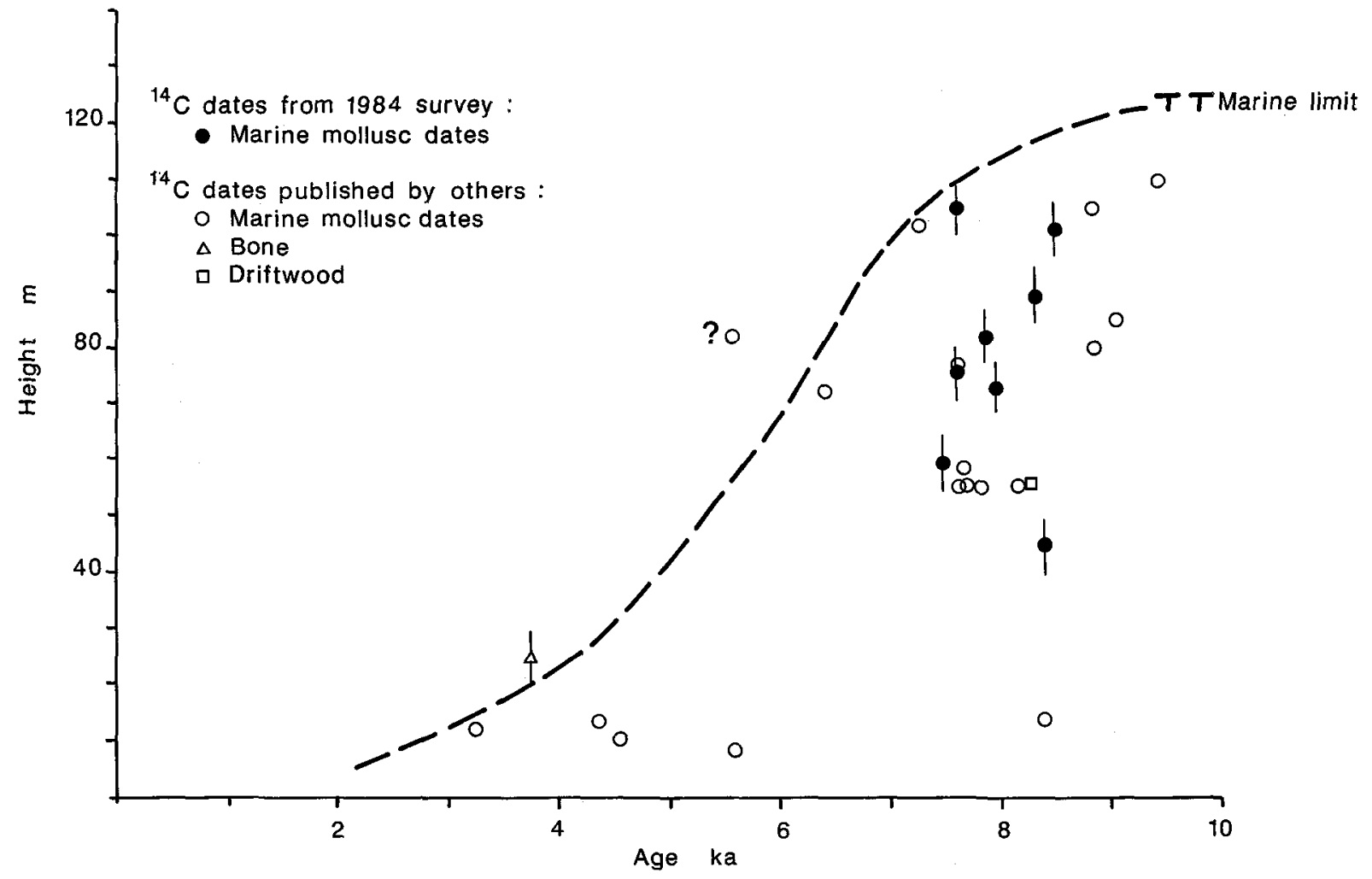

Fig. 8. Radiocarbon date evidence for sea level change and emergence curve for central Hall Land.

Island took place in a zone of down-warping outside the margin of the last glaciation. This follows from his different stratigraphic model for the area, according to which central Hall Land was not glaciated in the Late Weichselian (see alternative models below).

Thus, until further evidence is available there remains some uncertainty about the early history of emergence in Hall Land. The late history of sea level is also unknown, but it may end with a period of uplift, as occurred elsewhere in Greenland, e.g. the Sandnes transgression of West Greenland (Kelly, 1980; Funder, 1989). For the rest of western and central North Greenland, the sparse data indicate that emergence followed the same general trend as in the west, but perhaps at slightly slower rates. There is insufficient data to differentiate between the uplift histories of the outer and inner parts of the fjords.

\section{Warming Land stade (Early Holocene)}

The Warming Land stade is characterised by well developed ice-marginal deposits and features, particularly moraines, occurring about halfway down the fjord systems of the area, 20-60 km behind the Kap Fulford stade moraines. These are thought to have been formed during a phase in the retreat of the fjord glaciers from the Kap Fulford stade ice sheet, dating from around $>9.5 \mathrm{ka}$ to $8.0 \mathrm{ka}$. Although there is evidence of ice advance at this time in some places, it is not known whether this was due to climatic change or to ice dynamic factors as a result of changes in the configuration of ice sheet catchments during retreat.

Ice margin deposits and features from the Warming Land stade are particularly well represented on central Hall Land and the adjacent area of western Nyeboe Land. Also, these areas have received the most attention by other investigators.

At an early stage in the retreat of ice from central Hall Land, a glacial lake was dammed up between ice in Hall Basin, Nares Strait and Newman Bugt, as was first suggested by Koch (1928a, b). Silts without macrofossils occur up to $235 \mathrm{~m}$ above sea level on the north side of the valley and deltas on the south around the same height define an early stage in the development of this lake system. A deep overflow channel running north across the plateau may have been excavated at this time. Low arcuate ridges with clast rich surfaces running across the valley floor mark stages in the retreat of the ice during the evolution of the lake.

At a late stage, major ice margin features were 
formed across both the western and eastern ends of the central valley by ice in Hall Basin and Newman Bugt. In the west, this is the Polaris Bugt moraine of Dawes (1987), which has been described by Koch (1928a, b,), Davies et al. (1959), Weidick (1971) and England (1985) (his 'Petermann moraine'). In the east, it is the Newman Bugt moraine of Dawes (1987), which was described also by Koch (1928a, b), Davies et al. (1959), Weidick (1971) and England (1985) (his 'Newman moraine').

The Polaris Bugt lateral moraine forms a ridge 20-25 $\mathrm{m}$ above the surrounding valley floor, with its crest at around $106 \mathrm{~m}$ above sea level at the river of the Atka Elv, from which it rises both to the north and south (Fig. 9). Beyond the valley wall to the north it may be continued by the $24 \mathrm{~m}$ high sharp-crested moraine which runs around the lip of the plateau at about $250 \mathrm{~m}$ above sca level near Thank God Harbour, as was shown by Weidick (1971) and Dawes (1987), and suggested by Kelly \& Bennike (1985) and Bennike et al. (1987). To the south, the ice margin position corresponding to the Polaris Bugt moraine can be traced along the coast southwards towards Kap Tyson as a series of kame terraces and shallow marginal drainage channels. Its probable continuation south of the Kap Tyson headland is a well developed system of moraines at up to $460 \mathrm{~m}$ above sea level, which define the margin of a side lobe of the fjord glacier which entered the valley to the east (Petermann Fjord moraine of Dawes (1987)). Retreat stages of this lobe are linked to the formation of a series of gravel deltas/kames. England's (1985) view that a glacier flowed west, out of the valley, is considered to be incorrect.

At the Atka Elv the Polaris Bugt moraine has a core of boulder gravel, but this is draped by at least several metres of sorted sediments, including laminated silts and sands. Most of this sorted material has a coarse clast content which forms a lag gravel at the surface and gives the ridge its distinctive surface appearance. This clastrich facies extends outside the limits of the ridge, where its outcrop contrasts markedly in appearance with that of younger clast-poor marine silts and sands. Exposures south of the river show glacio-tectonic slices of silts included in the ridge. Here the feature is clearly a push moraine. Elsewhere, the moraine is thought to have been subaqueously deposited at least in its lower parts, at a time when the glacial lake level was falling towards an altitude of $125 \mathrm{~m}$ when the sea invaded the area.

On the east side of Hall Land, marginal drainage channels and associated kames at the north-east corner of the central lowland, from 150-220 m above sea level, mark the retreat of the ice in Newman Bugt which presumably formed the eastern margin of the glacial lake in this central valley. Below these features the broad ridge of the Newman Bugt moraine crosses the lowland at about $60 \mathrm{~m}$ above sea level and is cut through by the river 'Grăstenelv'. It is analogous in its position to the Polaris Bugt moraine in the west and like that it is lithologically complex, including clast-rich sorted sediments and till, both of which contribute to the surface of lag gravel. North of 'Grastenelv' the surface of the moraine is irregular and clast-poor marine sediments infill depressions on its surface. To the south the moraine rises to over $100 \mathrm{~m}$ above sea level and is then continued by a series of marginal channels between elevations of $230-290 \mathrm{~m}$.

Glacial lake formation was a notable feature of the Warming Land stade elsewhere in western and central North Greenland, with large systems of lakes dammed

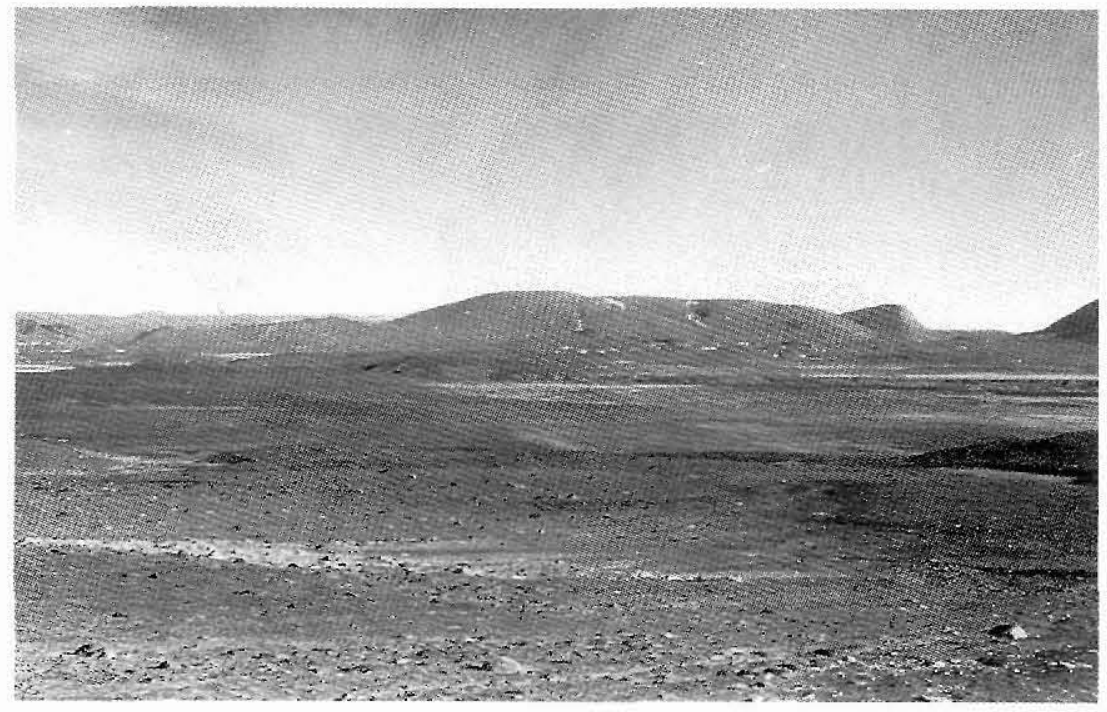

Fig. 9. Polaris Bugt moraine (Hall Land) looking along its length to the south, showing degraded "washed" appearance and (lighter coloured) Holocene marine sediments on either side (right and extreme left). 


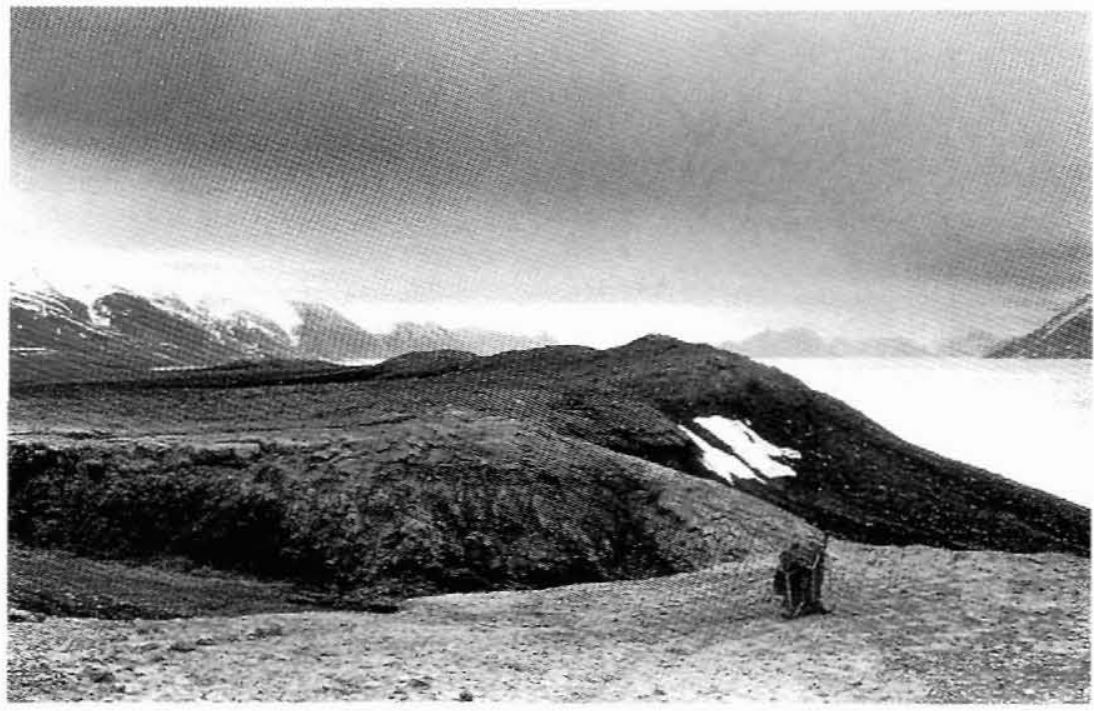

Fig. 10. Warming Land stade lateral moraine at edge of J. P. Koch Fjord, looking south-east. The gully section shows a thick sequence of distorted glaciolacustrine sediments.

up in deglaciated valleys by the glaciers in the fjords. On Nansen Land, large glacial lakes were formed in the broad lowland across the peninsula, by the retreat of the Warming Land stade ice in the fjords at either end of the valley, i.e. J. P. Koch Fjord and Brainard Sund (Fig. 10). On Wulff Land the early retreat of the ice from the north of the peninsula left an ice dammed lake, or lakes, in the central east-west lowland, dammed up by the glacier lobes in Sherard Osborne Fjord and Victoria Fjord. In this valley, glacio-lacustrine and glacio-fluvial deposits mantle arcuate ridges which mark the retreat stages of the ice margin in Victoria Fjord. At Kap Wallén, with ice in the fjord more advanced than in the adjacent valleys on land, outwash from the valley glaciers built a series of deltas into the lake between 110 and $200 \mathrm{~m}$ above sea level as the lake level fell with the progressive retreat of the fjord ice. The lowest of these deltas may have been controlled by sea level.

In the southern parts of the peninsulas, during the Warming Land stade, glacier lobes from the ice sheet margin flowed northwards down the U-shaped valleys cut in the limestone plateaux. During the retreat of the ice sheet the ice stagnated in these narrow valleys, developing extensive dead ice terrain, e.g. in Wulff Land, Warming Land and Nyeboc Land (Fig. 11).

The age of the Warming Land moraines is given by their relationship to the local marine limit and/or radiocarbon dated faunas from the Nyboe Land marine event.

The age of the moraine systems in central Hall Land
Fig. 11. Dead-ice deposits in valley systems in the carbonate plateau region, southern Wulff Land.

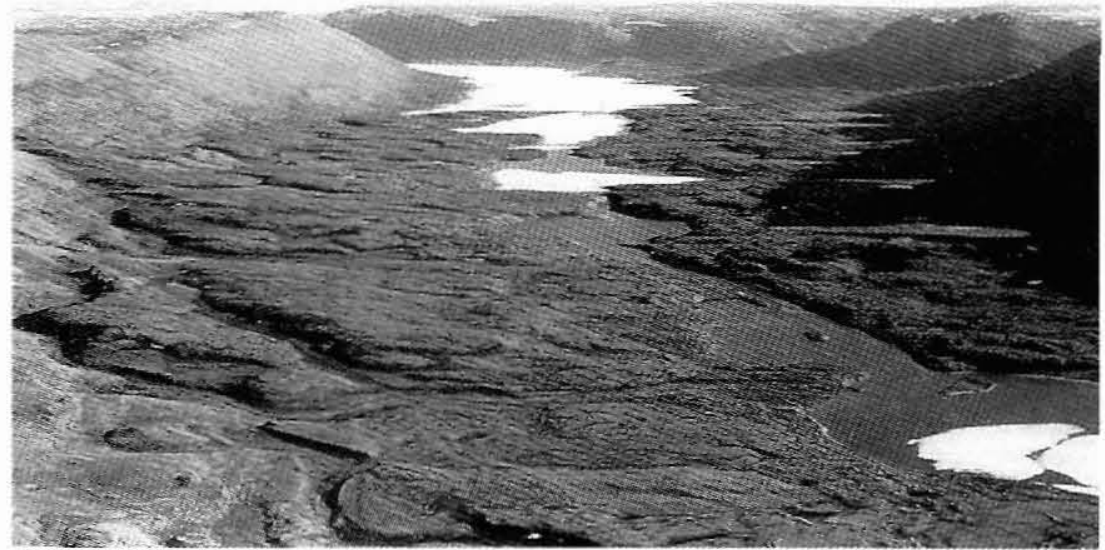


is a critical point in the dating of the Warming Land stade, and in the chronology of the alternative stratigraphies (see below). The minimum age of the Polaris Bugt moraine is provided by a wash limit which cuts its northern end at $125 \mathrm{~m}$ above sea level, and which is equated with the shoreline features in the valley to the east at the same height. This we consider to be the Nyeboe Land marine event transgression limit in the area, which is radiocarbon dated to $>9.4 \mathrm{ka}$ (England, 1985 ) and $>8.6 \mathrm{ka}$ (Weidick, 1978a). The age of the southern portion of the moraine south of Kap Tyson is less certain. Silts without macrofossils are present up to $111 \mathrm{~m}$ above sea level and a large gravel delta at an altitude of $127 \mathrm{~m}$ may have been controlled by the ice or sea. The oldest dated marine faunas from $69 \mathrm{~m}$ above sea level give an age of $7.5 \mathrm{ka}$.

Apparently, however, the ice was sufficiently near and active to influence sedimentation in the central part of western Hall Land until about $8 \mathrm{ka}$. Thus, the transition from the clast poor to the clast rich facies of sorted sediments on the east flank of the moraine at $82 \mathrm{~m}$ above sea level is dated to $>7.9 \mathrm{ka}$ by Hiatella arctica and Mya truncata in life position just above the boundary. In contrast Arca glacialis, from a distinctive fauna with Portlandia arctica, Palliolum greenlandicum and Limatula hyperborea, gave a date of $8.0 \mathrm{ka}$ for clast bearing, well consolidated silts on the proximal side of the moraine. Shells on top of the moraine in the surface lag deposit at $106 \mathrm{~m}$ above sea level also gave a date of $7.5 \mathrm{ka}$.

The evidence for the position of the marine limit in eastern Hall Land agrees well with that from the west. It is located at shoreline features from 117-124 m above sea level which are thought to be of marine rather than glacial origin. Nearby marine faunas at $104 \mathrm{~m}$ above sea level date this to $>8.5 \mathrm{ka}$. Similarly, marine sediments on the east side of Newman Bugt put the height of the limit at $>116 \mathrm{~m}$ above sea level and molluses at $106 \mathrm{~m}$ date it to $>8.8 \mathrm{ka}$. Radiocarbon dates obtained by England (1985) from near the base of the clast-poor sediments put the transition from the clast-rich facies at 'Gråstenelv' to 7.6-7.8 ka.

Further east, in Warming Land, a major lateral drainage channel from the Warming Land stade ends in a delta at $104 \mathrm{~m}$ above sea level, built out into the sea, or perhaps a lake, in Hartz Sund. This, and marine faunas younger than the ice margin deposits, date the stade to 7.7-8.5 ka. On Wulff Land, the retreat of ice in Victoria Fjord from Kap Wallén and the draining of the icedammed lake there is dated by the lowest delta associated with the lake at $110 \mathrm{~m}$ above sea level, and a marine fauna at $71 \mathrm{~m}$, giving an age range of $7.9-8.5 \mathrm{ka}$. On Nansen Land, the last stage of retreat of the J. P.
Koch Fjord glacier from the southern end of the central valley is associated with a marine limit $<83 \mathrm{~m}$ above sea level, which dates it to 7.5-8.0 ka. At the northern end of the valley the last stage of retreat of the ice in Brainard Sund from the mouth of the central valley is dated by a marine fauna at $41 \mathrm{~m}$ above sea level to $>7.4 \mathrm{ka}$.

If the correlation of these moraines with a broadly defined Warming Land stade is correct, it suggests that the stade began before c. $9.5 \mathrm{ka}$. According to this reconstruction, glaciers or calf-ice continued to influence sedimentation until 7.5-8 ka. In Hall Land, by 7.5 ka the ice had retreated into inner Petermann Fjord and Newman Bugt and clast-poor sediments were being deposited whilst, in the other fjord systems, glacier retreat drained the glacial lake systems.

\section{Steensby stade (Late Holocene)}

It appears that the retreat from the Warming Land stade brought the ice sheet to a size similar to its present one by the middle Holocene, at about $6 \mathrm{ka}$. Retreat then continued for an unknown period before the start of the Steensby stade advance, from the maximum of which the outlet glaciers have retreated slightly to their present positions. Historical records date the maximum to about the beginning of the present century. Local ice caps also grew in this stade, covering areas last glaciated by the ice sheet in the Kap Fulford stade. It seems likely that during the Holocene many of the smaller ice caps have existed only during the Steensby stade.

The date of deglaciation of the zone adjacent to the present margin, and, hence, the date of retreat of the ice sheet to a size equal to the present can be estimated from the ages of the marine limits near the present ice margin. These range from $>7.5 \mathrm{ka}$ at Petermann Gletscher in the west to $6.0 \mathrm{ka}$ at Ryder Gletscher in the centre of the region and $5.6 \mathrm{ka}$ at Henson Gletscher in the east.

Commonly, during the subsequent Steensby stade readvance the fjord glaciers overrode older Nyeboe Land marine sediments, and the reworked marine faunas provide a minimum age for the commencement of the readvance. Reworked shells in the present moraines are dated to $5.0 \mathrm{ka}$ at C. H. Ostenfeld Gletscher in Victoria Fjord and, by Weidick (1977b), to $4.2 \mathrm{ka}$ at Henson Gletscher (originally reported as Adam Gletscher) in J. P. Koch Fjord. In addition, at Steensby Gletscher, reworked marine shells occur in the lateral moraine of the present glacier and marine silts, with a fauna dated to $4.7 \mathrm{ka}$, outcrop $12 \mathrm{~km}$ behind its front. In addition, peat deposits with an age of $5.1 \mathrm{ka} 100 \mathrm{~m}$ above sea level from the ice sheet margin north of Ryder Gletscher at $280 \mathrm{~m}$ above sea level indicate the 
Fig. 12. Local glaciers on Nares Land (looking south) overriding a Kap Fulford stade glaciolacustrine shoreline (line along valley side on bottom left).

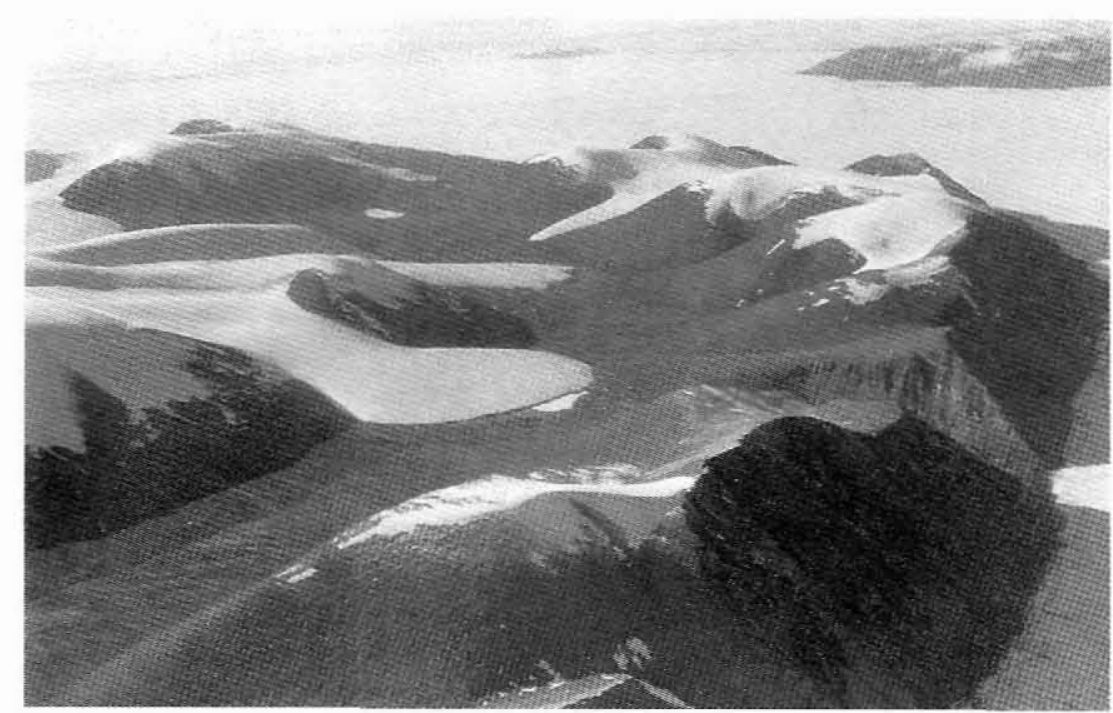

age of the terrain over which the ice margin has advanced on the plateau.

The best evidence for the date of the Steensby stade advance maximum is from Petermann Gletscher, which is the major outlet glacier from the ice sheet in the west of the area. The floating terminus of this glacier is better defined than the other major outlet glaciers, because the ice free conditions allow escape of calf-ice into Nares Strait, and the changes in its frontal position are clearer. From 1876 to 1922 the margin was relatively stable, at a position which was probably close to the maximum for the Steensby stade (Koch, 1928a; Davies \& Krinsley, 1962). Since then the ice margin has retreated $c .6 \mathrm{~km}$. The damming back of calf-ice by fjord ice in the other fjords of the area leads to a poorly defined, disintegrated floating ice tongue, making accurate description of the fluctuations of the margins of these glaciers difficult. Steensby Gletscher, Ryder Gletscher and C. H. Ostenfeld Gletscher probably reached their maximum positions around the turn of the century. Since then Steensby Gletscher has thinned and withdrawn only by a few metres from its west margin (Ahnert, 1963), whereas the other two have retreated considerably by disaggregation of their floating tongues (Koch 1928a; Davies \& Krinsley, 1962).

Local ice caps throughout the area have reached their maximum post-Weichselian extent in the Steensby stade. This advance has brought lobes from the present plateau ice caps into valleys which have not been glaciated since they were occupied by ice from an ice sheet, or by related glacial lakes, during the Kap Fulford stade (northern Wulff Land and Nares Land) or Warming Land stade (Warming Land). Also on the plateaux, features and deposits containg gneiss erratics formed by the ice sheet during these older stades, lic adjacent to the present local ice cap margins, whereas ice cap moraines are absent (Fig. 12).

\section{Alternative stratigraphic models}

There is stratigraphic, amino acid and ${ }^{14} \mathrm{C}$ evidence for at least two episodes with marine incursions related to glacio-isostatic subsidence in the region: the Hall Land and Nyeboe Land marine events (Fig. 2). The complete lack of marine faunas with intermediate amino acid or ${ }^{14} \mathrm{C}$ ages suggests that these were two separate events, separated by a period of low sea level and/or glaciation of the area. The evidence that the older event involved a substantial transgression comes only from England's (1985) reports of in situ marine sediments, which we assign to that event. Our data from glacially reworked faunas are not themselves direct evidence for a transgression.

Whereas two separate marine events have been proposed above, a poorly known Eemian/Early Weichselian event and better known end Weichselian/Holocene event. England $(1985,1987)$ considered that over part of the present land area a "full-glacial sea" persisted from the Early or Middle Weichselian to the Holocene, over a period from $>33 \mathrm{ka}$ to $8.2 \mathrm{ka}$. The area affected was considered to be an isostatically depressed region of Nares Strait, which included the central zone of Hall Land and the adjacent areas. This model was based on evidence from Ellesmere Island, together with the presence in the adjacent part of Hall Land of in situ marine sediments which apparently had not been overridden by ice and which had faunas giving either non-finite or Holocene ${ }^{14} \mathrm{C}$ ages. This model conflicts with ours be- 


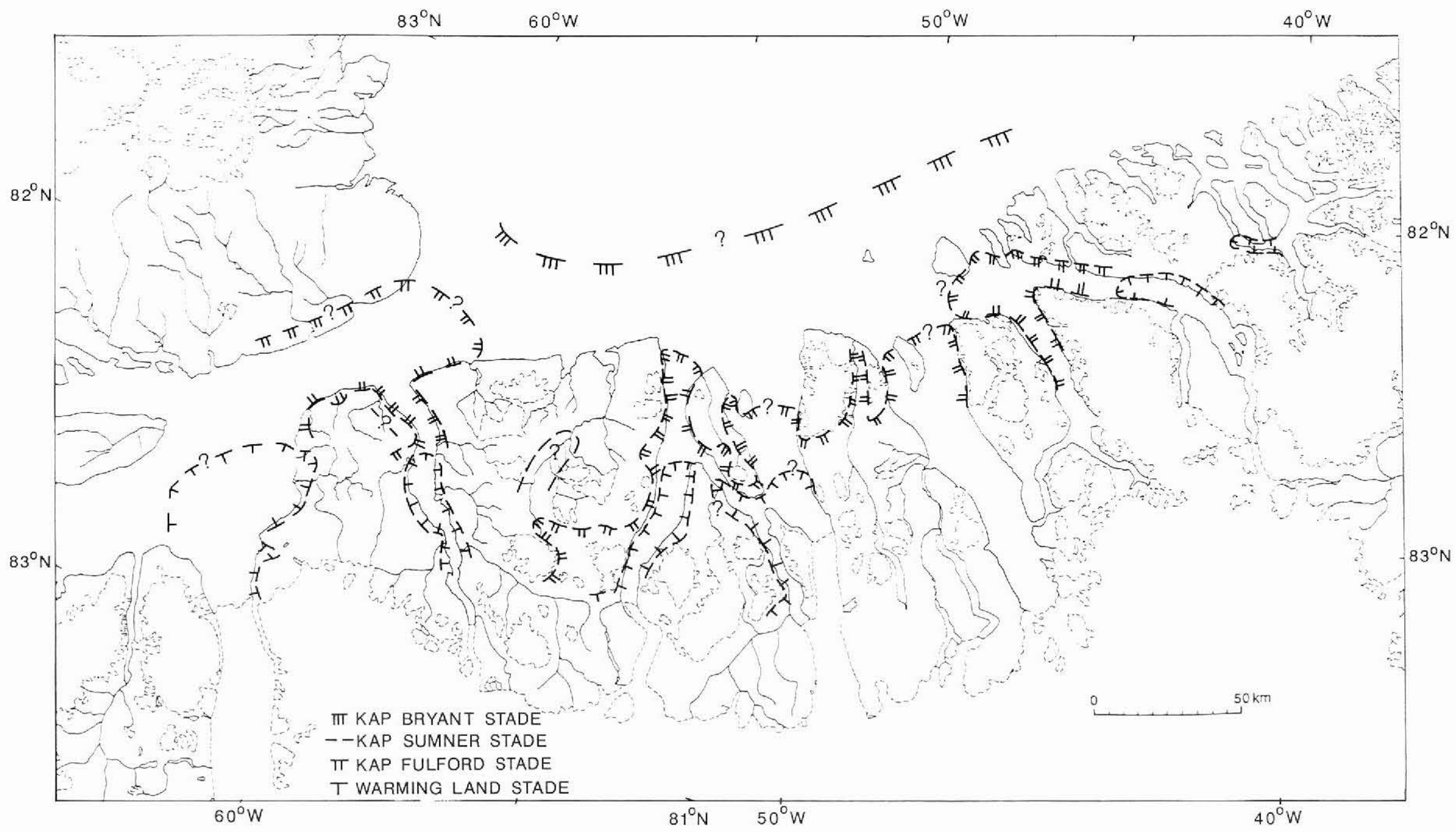

Fig. 13. Reconstruction of past ice margins for western and central North Greenland. 


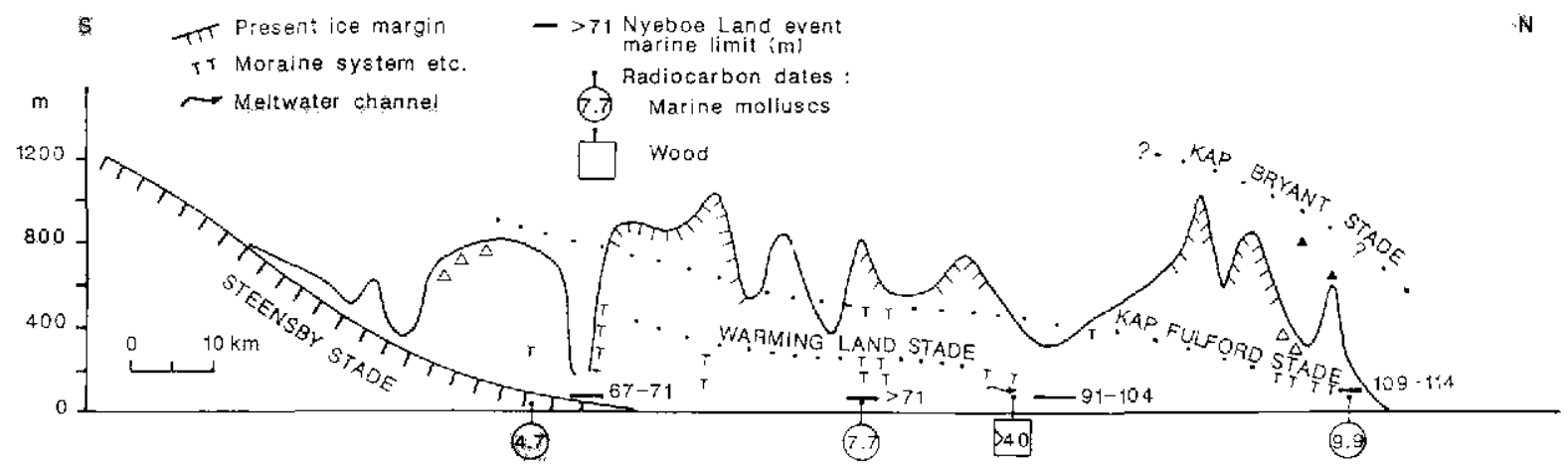

Fig. 14. Cross-section along Sankt George Fjord showing the relationship of the glacial stades (open triangles: till, solid triangles: key erratics).

cause the whole of this area of the "full-glacial sea" should have been overridden by the Kap Fulford stade ice. Whether or not England's critical site in Hall Land was overridden necds to be re-examined in the field. Also, a major weakness in this model is the absence of marine deposits dated to the interval between $>33 \mathrm{ka}$ and $10 \mathrm{ka}$, either in this part of Grecnland or in the adjacent part of Ellesmere Island.

In another possible stratigraphic model, the Hall Land moraines belong to the maximum phase of a Late Weichselian - Early Holocene glaciation, rather than a retreat phase as in our model (Warming Land stade). This would effectively relate the Nyeboe Land marine event transgression to the isostatic depression associated with the Warming Land stade, and would put the Kap Fulford stade much further back in time. This alternative model has its roots in the early work of Koch (1928a, b) and Davies (1972). It is also close to that favoured by England (1985, 1987), except that he proposed a more or less stable ice front at the position of the Warming Land stade moraines from $>33 \mathrm{ka}$ to 8.2 $\mathrm{ka}$, and a prolonged interval of high relative sea level throughoul this period (see discussion in previous paragraph). The principle argument against this is the state of preservation of the Kap Fulford stade landforms and their relationship to the Nyeboe I and marine event deposits at Kap Fulford, described earlier. Apart from the difference in the dating of the events in Hall Land, Davies' (1972) interpretation of events in Hall Land is very similar to ours, and he recognises four of our five periods of glaciation.

A Late Weichselian age for the central Hall Land moraines would also be possible if the correlation of the moraines at Kap Ammen and Kap Sumner (younger moraines) with the Kap Fulford stade was incorrect. This, however, would require a less cxpanded ice cover over Hall Land than further east, the opposite of the present situation.

The model of Dawes (1987) for the I Lall Land stratigraphy is also basically similar to ours, except that he appears to suggest a closer time relationship between the Kap Fulford stade moraines (at Kap Ammen and Kap Sumner) and the Warming land stade moraines (Polaris Bugt and Newman Bugt moraines). Whilst this links what appear to be identical morphostratigraphic boundaries, the resultant ice surface profile is unrealistic.

\section{Reconstructed ice margins and profiles}

Hypothetical ice margins for the glacial stades of our stratigraphic model are shown in Fig. 13, and longitudinat ice surface profiles. for the Sankt George Fjord areal in Fig. 14. 


\section{History and environmental evidence of biota}

\section{Pre-Holocene marine biota}

Only species with robust shells occur in the reworked fauna: Balanus balanus, Tridonta sp., Hiatella arctica and Mya truncata (Table 3). The barnacle Balanus balanus is relatively common in the reworked faunas but is apparently absent from Holocene deposits, both in this region and eastern North Greenland (Bennike et al., 1986). The significance of this difference is not entirely clear. The modern northern limit of B. balanus is poorly known, but the British Arctic Expedition, which undertook dredging in Nares Strait, collected it only from the southern part (Miers, 1877). Also, the species is common in Eemian, Early Weichselian and Holocene deposits in the Thule area of north-west Greenland (Funder, 1990).

\section{Holocene marine biota}

Calcareous invertebrate fossils are common throughout the region in the raised deposits of the Nyeboe Land marine event. The species of macroscopic invertebrates identified are shown in Table 4. All the undated occurrences in this table are considered from their field contexts to be probably of Holocene age. Overall, the fauna is distinguished from the Holocene faunas of West and East Greenland (e.g. Noe-Nygaard, 1932; Laursen,
1950; Kelly, 1973; Donner \& Jungner, 1975; Funder, 1978) by its lower diversity and by the presence of a number of species known in Holocene faunas only from North Greenland, i.e. Trichotropis borealis, Portlandia frigida and Limatula hyperborea (Bennike et al., 1986). Two other species, Siphonodentalium lobatum and Thracia devexa have been recorded once from East Greenland (Noe-Nygaard, 1932; Petersen, 1986). These five species, together with the other Portlandia species, comprise a characteristic cold adapted component in the fauna.

There is an element of succession in the appearance of species, which may be partly due to local environmental changes, i.e. facies faunas, but also appears to reflect a regional immigration sequence of species. The oldest faunas, comprising species adapted to cold turbid waters near ice margins, Cyclogyra foliaceae, Portlandia arctica and Palliolum greenlandicum, date from the initial retreat of the Late Weichselian ice, e.g. $9.9 \mathrm{ka}$ in northern Nyeboe Land, and at $112 \mathrm{~m}$ above sea level in central Hall Land where a similar fauna was dated by England to $9.4 \mathrm{ka}$. However, these species, and the specifically North Greenland fauna referred to above, are not restricted to a particular part of the Holocene. Hiatella arctica, which dominates most faunas, was common from at least $8.8 \mathrm{ka}$ whereas Mya truncata is rare before $8.3 \mathrm{ka}$. Tridonta borealis may be a late immi-

Table 3. Pre-Holocene marine faunas, western and central North Greenland

\begin{tabular}{|c|c|c|c|c|c|c|c|c|c|c|c|c|c|c|c|c|}
\hline Locality number & 5 & 7 & 8 & 9 & 12 & 12 & 13 & 13 & 13 & 23 & 23 & 24 & 29 & 37 & 37 & 48 \\
\hline Sample no. GGU 313- & 885 & 892 & 912 & 913 & 857 & 858 & 901 & 895 & 894 & 851 & 852 & 855 & 837 & 943 & 945 & 829 \\
\hline
\end{tabular}

CIRRIPEDIA

Balanus balanus (Linné)

BIVALVIA

Tridonta sp.

Hiatella arctica (Linné)

Mya truncata Linné

$\begin{array}{llll}\cdot & s & \cdot & \\ \cdot & s & s & s \\ s & \cdot & \cdot & s\end{array}$

$\begin{array}{lll}\mathrm{s} & \mathrm{s} & \\ \mathrm{s} & \mathrm{s} & \mathrm{c} \\ \mathrm{s} & \mathrm{s} & \end{array}$

$\begin{array}{lllllll}\mathrm{s} & \cdot & \mathrm{s} & \cdot & \cdot & \mathrm{s} & \mathrm{s} \\ \mathrm{s} & \mathrm{s} & \mathrm{s} & \cdot & \mathrm{s} & \mathrm{s} & \mathrm{s} \\ \cdot & \cdot & \cdot & \cdot & & & \end{array}$

Height $m$ above sea level

$47 \quad 139$

$\begin{array}{llll}230 & 352 & 300 & 227\end{array}$

$19 \quad 102 \quad 140$

$136 \quad 20$

$215 \quad 102$

$\begin{array}{lll}46 & 108 \quad 62\end{array}$

C-14 age ka

$>27.5$. $>27.5$

Frequency categories: c - common, s - scarce; ? - Pre-Holocene age uncertain. See fig. 1 for localities. 
grant, being a dominant species only in younger faunas, including two dated to 5.3 and $4.5 \mathrm{ka}$. A single fragment of this species from a $9.2 \mathrm{ka}$ fauna may be derived from the older Hall Land marine event. Serripes groenlandicus and Macoma calcarea appear to be the species most limited in space and time, known only from Newman Bugt at $4.5 \mathrm{ka}$. These species are unknown in Holocene faunas from elsewhere in North Greenland, but are abundant in West Greenland faunas. Relatively little is known about present day faunas in North Greenland but Macoma calcarea has been found in Jørgen Brønlund Fjord, eastern North Greenland (Schiøtte, 1989). However, the absence of these species from other Holocene faunas suggests that the isolated occurrence in Newman Bugt may mark a period of ameliorated conditions.

The vertebrate marine fauna of the period is represented only by an otolith of Boreogadus saida (Polar cod) and by bones of Phoca hispida (Ringed seal). A ringed seal skeleton from Hall Land was dated to 8.7 ka, which is the oldest known Holocene mammal from Greenland (Bennike et al., 1989).

\section{Holocene driftwood}

Except in Nares Strait, more or less permanent sea ice exists along the coast today, and driftwood is rarely deposited. Ten driftwood pieces were found in the area, of which only four were from altitudes above $1.5 \mathrm{~m}$ (at $4,16,42$ and $44 \mathrm{~m}$ above sea level) and thus undoubtedly fossil. The wood was identified as Larix sp. (5 pieces), Picea sp. (2), Larix or Picea (2) and Pinus sp. (1). The dominance of Larix suggests that the driftwood is of Siberian origin since the North American boreal forest is dominated by Picea. None of the samples have been dated, but England (1985) reports a date of $8.3 \mathrm{ka}$ for a wood sample from western Hall Land at $56 \mathrm{~m}$ above sea level, which is old for that elevation. It shows that sea ice conditions allowed entry of driftwood into northern Nares Strait in the early Holocene.

\section{Pre-Holocene terrestrial biota}

In Warming Land, organic laminae occur in lacustrine silts and sands (Skalhøjene unit) beneath a till dated to the Kap Fulford/Warming Land stades. The bulk orga- nic matter and an individual twig have ${ }^{14} \mathrm{C}$ ages which are probably both minimum ages $(32.3 \mathrm{ka}$ and $>40 \mathrm{ka})$. The species identified, described in Meldgaard \& Bennike (1989), indicate the presence of both terrestrial and aquatic plant communities similar to those found in North Greenland today.

\section{Holocene terrestrial biota}

A limited amount of information about the terrestrial biota and environmental conditions is provided by two organic deposits.

In southernmost Wulff Land, a peat deposit is situated only about $100 \mathrm{~m}$ from the present glacier margin, at $279 \mathrm{~m}$ above sea level. The peat, which is up to $3.5 \mathrm{~m}$ thick and underlain by till, is rich in aeolian sand, especially in its lower part. Five samples were analysed for their content of macroscopic plant and animal remains and the results are given in Appendix 2. A radiocarbon date of $5.1 \mathrm{ka}$ gives a minimum date for the immigration to the area of the species identified. The peat deposit was formed by a Carex stans marsh, as is clearly shown by the abundance of Carex stans achenes, some of which are still enclosed in their utricule. The Dryas, and perhaps also the Salix remains, could come from marsh hummock communities or were blown into the marsh from surrounding drier areas. The deposit contains only a few fragments of mosses, probably because their growth was impeded by deposition of wind blown sand. All the species identified occur in the region today and there is no evidence for a different climatic regime at that time.

In northern Wulff Land (Fig. 1, loc. 37), a silt lens in fluvioglacial gravel at about $72 \mathrm{~m}$ above sea level contains an abundance of filamentous algae which still retain a green colour. Other plant and animal remains besides the algae (Appendix 4) showed that the deposit was formed in a pond on a floodplain. The deposit has a ${ }^{14} \mathrm{C}$ age of $10.5 \mathrm{ka}$.

The only other evidence about the history of the terrestrial fauna and flora in the Holocene comes from dated mammal bones. This information, summarised by Bennike et al. (1989), indicates that much of the present mammalian fauna was present in the Middle Holocene and that the reindeer (Rangifer tarandus pearyi), at least, was present in the Early Holocene. 
Table 4. Holocene marine faunas, western and central North Greenland

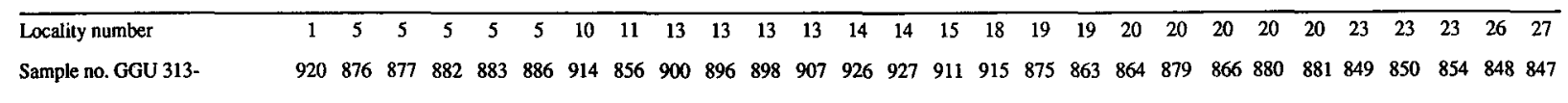

FORAMINIFERA

Cyclogyra foliaceae (Philippi)

POLYCHAETA

Caulostrepsis ichnosp.

Serpulidac

GASTROPODA

Trichotropis borealis Broderip

\& Sowerby

Colus togatus (Mrrch)

Buccinum hydrophanum

Hancock

Oenopota sp.

Cylichna alba (Brown)

Cylichna sp.

Siphonodentalium lobatum

(Sowerby)

BIVALVIA

Nuculana pernula (Loche)

Portlandia arctica (Gray)

Portlandia intermedia M. Sars

Portlandia lenticula (Möller)

Portlandia frigida (Torell)

Arca glacialis Gray

Palliolum greenlandicum

(Sowerby)

Limatula hyperborea (Jensen)

Tridonta borealis (Schumacher)

Serripes groenlandicus

(Bruguière)

Macoma calcarea (Gmelin)

Thyasira gouldi (Philippi)

Hiatella arctica (Linné)

Mya oruncata Linné

Thracia devexa G. O. Sars

PISCES

Boreogadus saida (Lepechin)

\section{MAMMALIA}

Phoca hispida Schreber

\begin{tabular}{lllllllllllllllllllllllllllll}
\hline Height m above sea level & 69 & 105 & 73 & 44 & 82 & 80 & 76 & 31 & 101 & 89 & 63 & 73 & 109 & 112 & 116 & 59 & 15 & 104 & 29 & 13 & 11 & 14 & 14 & 28 & 95 & 66 & 68 & 77 \\
C-14 age ka (corrected) & 7.5 & 7.5 & 7.9 & 8.0 & 7.9 &. & 7.6 &. & 8.8 & 8.3 &. &. &. &. &. & 7.5 &. & 8.5 &. &. & 4.5 &. &. & 5.4 &. &. &. &. \\
\hline
\end{tabular}

Frequency categories: a - abundant, c - common, s - scarce. See Fig. 1 for localities. 


\begin{tabular}{lcccccccccccccccccccccccccccc}
\hline Locality number & 30 & 30 & 30 & 33 & 34 & 36 & 38 & 38 & 40 & 40 & 42 & 42 & 42 & 42 & 44 & 45 & 46 & 46 & 46 & 46 & 46 & 51 & 52 & 53 & 54 & 54 & 54 \\
Sample no. GGU 313- & 839 & 841 & 842 & 936 & 940 & 948 & 941 & 942 & 801 & 802 & 810 & 811 & 812 & 814 & 833 & 949 & 815 & 816 & 817 & 822 & 823 & 932 & 830 & 930 & 826 & 828 & 831
\end{tabular}

\section{FORAMINIFERA}

Cyclogyra foliaceae (Philippi)

\section{POLYCHAETA}

Caulostrepsis ichnosp.

Serpulidae

\section{GASTROPODA}

Trichotropis borealis Broderip

\section{\& Sowerby}

Colus togatus (Mörch)

Buccinum hydrophanum Hancock

Oenopota sp.

Cylichna alba (Brown)

Cylichna sp.

Siphonodentalium lobatum

(Sowerby)

BIVALVIA

Nuculana pernula (Leche)

Portlandia arctica (Gray)

Portlandia intermedia M. Sars

Portlandia lenticula (Moller)

Portlandia frigida (Torell)

Arca glacialis Gray

Palliolum greenlandicum

(Sowerby)

Limatula hyperborea (Jensen)

Tridonta borealis (Schumacher)

Serripes groenlandicus (Bruguière)

Macoma calcarea (Gmelin)

Thyasira gouldi (Philippi)

Hiatella arctica (Linné)

Mya truncata Linné

Thracia devexa G. O. Sars

PISCES

Boreogadus saida (Lepechin)

\section{MAMMALIA}

Phoca hispida Schreber

\begin{tabular}{llllllllllllllllllllllllllllll}
\hline Height m above sea level & 91 & 93 & 87 & 4 & 24 & 69 & 63 & 9 & 26 & 7.5 & 4.5 & 4.5 & 49 & 28 & 62 & 5 & 40 & 79 & 12 & 23 & 11 & 11 & 4.5 & 71 & 39 & 41 & 3 \\
C-14 age ka (corrected) &. & 8.8 & 9.9 &. & 4.7 & 7.7 &. & & 5.9 &. &. &. &. & 6.6 & 7.9 & 5.0 & $\cdot$ &. &. &. &. & 5.6 & $\cdot$ & 9.2 &. & 7.4 &. \\
\hline
\end{tabular}

Frequency categories: a - abundant, c - common, s - scarce. See Fig. 1 for localities. 


\section{Regional correlation}

The history of glaciation in western and central North Greenland is obviously linked to that of the adjacent areas of Greenland: eastern North Greenland and north-west Greenland, and to that of Ellesmere Island, which faces Greenland across the narrow Nares Strait. The suggested correlation between the Late Quaternary stratigraphies of these areas is shown in Fig. 15 and discussed below. In broad terms, the chronostratigraphy suggested for the region is in agreement with that proposed for all other parts of Greenland, i.e. the last major glaciation of the area was in the Late Weichselian and an earlier, considerably more extensive glaciation dates probably from the Saalian (Kelly, 1985; Funder, 1989).

The ${ }^{14} \mathrm{C}$ date for the Hall Land marine event is $>27.5$ ka but an estimate of its age can be made from the amino acid data. Two transgressive episodes with thermophilous marine faunas have been proposed for northwest Greenland: Kaffehavn and Meteorbugt marine events (Kelly, 1985, 1986), but as Funder (1989) has emphasised only the former is securely based on in situ material. The lower end of the range of values in the Hall Land aminozone (i.e. total alle/Ile of 0.035-0.057) overlaps with aminozones from West Greenland assigned to the Kaffehavn event (mean total alle/Ile of 0.031), which was considered to be Eemian on faunal and stratigraphic grounds (Kelly, 1986). Recent detailed work in the Thule district of north-west Greenland (Funder, 1990), including thermoluminescence dating, has shown that thermophilous faunas with amino acid values overlapping those of the Hall Land event (Thule aminozone, total alle/Ile of 0.021-0.049) date from both the Eemian and Early Weichselian, i.e. 69-136 ka.

On this basis, the Kap Bryant and Kap Fulford stades would correlate with the Bliss Bugt and Independence Fjord Glaciations defined by Funder (1989), from the adjacent area of eastern North Greenland. However, in

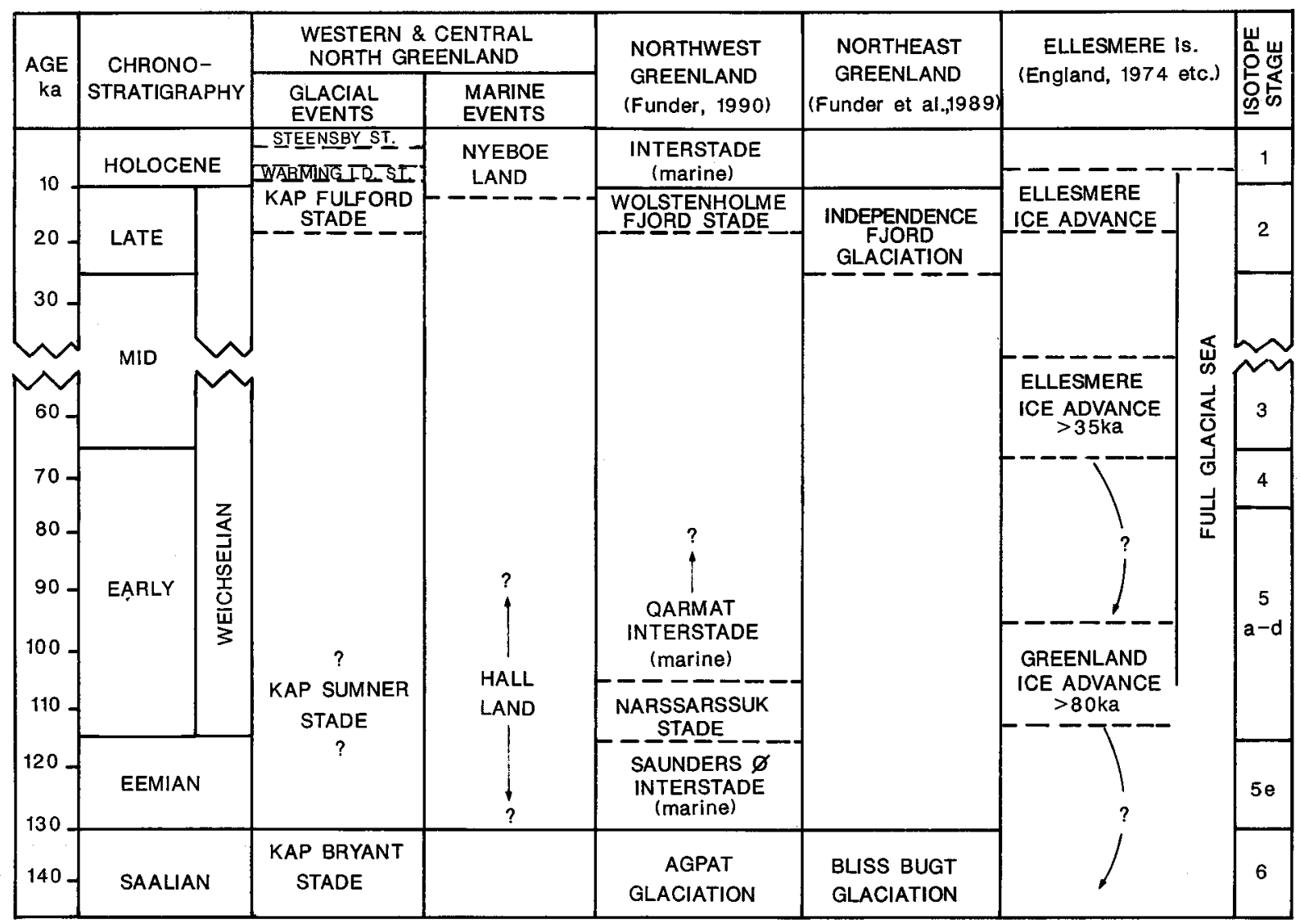

Fig. 15. Correlation of stratigraphic models for Late Quaternary of northern Greenland and Ellesmere Island. 
the Late Weichselian Independence Fjord glaciation, coalescing outlet glaciers are considered to have formed an ice shelf along the margin of the Arctic Ocean. On the evidence of the crystalline erratics present along the coast, the shelf ice was thought to have been moving from the west (Funder \& Larsen, 1982; Dawes, 1986). However, according to our model, in the adjacent area to the west, the Kap Fulford stade ice was not of sufficient thickness along the coast to generate a major ice shelf capable of transporting these erratics eastwards.

In both the Kap Bryant and Kap Fulford stades, the Greenland ice sheet must have impinged on Ellesmere Island. It has been recognised for some time that, in at least one period, the Greenland ice sheet extended over north-eastern Ellesmere Island (Christie, 1967). In the views of England and his co-workers (England, 1978: England \& Bradley, 1978; England et al., 1978; 1981), summarised by England (1987), this event occurred before $80 \mathrm{ka}$, whereas the Late Weichselian ice cover was formed by a relatively small advance of Ellesmere Island ice caps which did not reach to the coast of Nares Strait.

If our stratigraphic model for neighbouring North Greenland is correct, more than one advance of the Greenland ice sheet should have occurred over Ellesmere Island. Deposits and landforms containing Greenland erratics, which are present at high levels, e.g. up to $760 \mathrm{~m}$ above sea level on Judge Daly Promontory (Christie. 1967; England \& Bradley, 1978), could be correlated with the Kap Bryant stade, for which a similar age is suggested. However, it is clear from their position and preservation that deposits with Greenland erratics on the Ellesmere Island coast of Robeson Channel opposite Hall Land (Retelle, 1986) should correlate with the Kap Fulford stade.

From this part of Ellesmere Island, Retelle describes pre-Holocene marine deposits which could correlate with the Hall Land marine event, although the total alle/Ile values (0.057-0.077) for shells from the 'Robeson aminozone' correspond with the higher end of the Hall Land event. He considers that these deposits and faunas extend up to a marine limit, marked by a shoreline at $286 \mathrm{~m}$ above sea level. This indicates a considerable degree of isostatic subsidence which was twice the maximum found anywhere in Greenland from the later, although smaller, Late Weichselian glaciation. Since these, and other marine deposits with non-finite ages further south, are considered not to have been overridden by ice they are used as evidence for the prolonged period of high sea levels from $>80 \mathrm{ka}$ to the Holocene called the 'Full Glacial Sea' by England (1983, 1985, 1987). However, in the Robeson Channel area it is not clear from the descriptions whether the faunal remains above $90 \mathrm{~m}$ above sea level could be glacially reworked, nor whether the silt deposits and shoreline features at higher levels could be glacio-lacustrine in origin. Since the Kap Fulford stade ice sheet in Greenland has demonstrably overridden Hall Land marine event deposits of non-finite ${ }^{14} \mathrm{C}$ age, the evidence from the two areas is in conflict and further work is needed to reconcile the interpretations.

The Warming Land stade, dating from the early Holocene, corresponds to the early retreat phase of the Late Weichselian glaciation elsewhere in Greenland. In eastern North Greenland, Bennike (1987) has described a readvance from 8 to $9 \mathrm{ka}$. In West Greenland, it was marked by periods of moraine construction both local and regional, probably reflecting a combination of climatic and non-climatic controls between 7.5 and $9.8 \mathrm{ka}$ (Kelly, 1985). In East Greenland, the preceding glacial maximum did not end until $9.5 \mathrm{ka}$ and this was followed by a period of rapid retreat interrupted by local moraine construction (Funder, 1990). The Warming Land stade can also be correlated with the Hazen moraines of Ellesmere Island dated to $8.0 \mathrm{ka}$ (England, 1978).

Thus, our model of the Late Weichselian glaciation in western North Greenland lies between those suggested for eastern North Greenland and Ellesmere Island. This suggests that neither of the two extreme positions that have been taken by other investigators about the extent of the Late Weichselian Greenland-Ellesmere ice (summarised by Paterson (1977), England \& Bednarski (1986) and Hodgson (1989)) may be correct, i.e. there was neither a thick coalescing ice sheet nor a complete absence of ice cover in Nares Strait.

The stratigraphy suggested for the region most nearly compares with that of Northwest Greenland (Funder, 1990). There the Late Weichselian Wolstenholme Fjord stade belonging to the Sisimiut Glaciation (Kelly, 1985; Funder, 1989) extended only to the fjord mouth, whilst the main ice sheet glaciation of the area (Agpat Glaciation) was dated to the Saalian. In addition, an advance of intermediate scale was dated to the Early Weichselian (Narssârssuk stade). This was the first clear demonstration of glacial advances of this age in Greenland. It is suggested that the poorly known Kap Sumner stade from western and central North Greenland may correlate with this event.

The Nyeboe Land marine event, covering the period of regression following retreat of the ice from the Late Weichselian advance, correlates with marine events from the same period from West Greenland (Disko Bugt marine event (Kelly, 1985) and from East Greenland (Funder, 1989). However, the subsequent period of transgression in the Late Holocene (Sandnes transgression, West Greenland (Kelly, 1980) and East 
Greenland (Hjort, 1981)) is not known from North Greenland.

The recession of the Greenland ice sheet behind its present margin in the mid-Holocene has been described from many parts of Greenland (Funder, 1971; Kelly, 1980; Weidick et al., 1990). The subsequent advance is also a general feature of the Greenland ice sheet history. Thus, the Steensby stade correlates with the Vesterbygd glacial event of West Greenland, where the late Holocene advance of the Greenland ice sheet and local glaciers is well documented (Kelly, 1980, 1985). A cor- responding advance is reported also from eastern North Greenland (Funder \& Hjort, 1980).

Acknowledgements. We acknowledge especially the assistence and encouragement of $\mathrm{N}$. Henriksen who directed the expedition to western and central North Greenland. N. Henriksen and S. Funder kindly offered advice on the manuscript. The radiocarbon dates from the Copenhagen Laboratory were obtained by courtesy of the Geological Survey of Denmark. U. Røen kindly checked the identification of remains of freshwater animals.

\section{References}

Ahnert, F. 1963: The terminal disintegration of Steensby Gletscher, North Greenland. J. Glaciol. 4, 537-545.

Bennike, O. 1987: Quaternary geology and biology of the Jørgen Brønlund Fjord area, North Greenland. Meddr Grønland Geosci. 18, 23 pp.

Bennike, O. \& Kelly, M. 1987: Radiocarbon dating of samples collected during the 1984 expedition to North Greenland. Rapp. Grønlands geol. Unders. 135, 8-10.

Bennike, O., Funder, S. \& Hjort, C. 1986: Notes on the Holocene marine fauna of eastern North Greenland. Bull. geol. Soc. Denmark 35, 71-74.

Bennike, O., Dawes, P. R., Funder, S., Kelly, M. \& Weidick, A. 1987: The late Quaternary history of Hall Land: Discussion. Can. J. Earth Sci. 24, 370-374.

Bennike, O., Higgins, A. K. \& Kelly, M. 1989: Mammals of central North Greenland. Polar Record 25, 43-49.

Bessels, E. 1879: Die amerikanische Nordpol-Expedition, Leipzig: Von Wilhelm Engelmann, $647 \mathrm{pp}$.

Christie, R. L. 1967: Reconnaissance of the surficial geology of northeastern Ellesmere Island, Arctic Archipelago. Bull. geol. Surv. Can. 138, $50 \mathrm{pp}$.

Davies, W. E. 1963: Glacial geology of northern Greenland. Polarforschung 5, 94-103.

Davies, W. E. 1972: Landscapes of northern Greenland. Spec. Rep. Cold Reg. Res. Engng Lab. 164, 67 pp.

Davies, W. E. \& Krinsley, D. B. 1962: The recent regimen of the ice cap margin in North Greenland. Publs int. Ass. Scient. Hydrol. 58, 119-130.

Davies, W. E., Needleman, S. M. \& Klick, D. W. 1959: Report on Operation Groundhog (1958) North Greenland. Investigations of ice-free sites for aircraft landings, Polaris Promontory, North Greenland, 45 pp. Bedford: U.S.A.F. Cambridge Res. Center.

Dawes, P. R. 1977: Geological photo-interpretation of Hall Land: part of the regional topographical-geological mapping of northern Greenland. Rapp. Grønlands geol. Unders. 85, 25-30.

Dawes, P. R. 1986: Glacial erratics on the Arctic Ocean margin of North Greenland: implications for an extensive ice-shelf. Bull. geol. Soc. Denmark 35, 59-69.
Dawes, P. R. 1987: Topographical and geological maps of Hall Land, North Greenland. Bull. Grønlands geol Unders. 155, $88 \mathrm{pp}$.

Dawes, P. R. \& Frisch, T. 1981: Geological reconnaissance of the Greenland Shield in Melville Bugt, North-West Greenland. Rapp. Grønlands geol. Unders. 105, 18-26.

Donner, J. \& Jungner, H. 1975: Radiocarbon dating of shells from marine Holocene deposits in the Disko Bugt area, western Greenland. Boreas 4, 25-45.

England, J. 1978: The glacial geology of northeastern Ellesmere Island, N.W.T., Canada. Can. J. Earth Sci. 15, 603-617.

England, J. 1983: Isostatic adjustments in a full glacial sea. Can. J. Earth Sci. 20, 895-917.

England, J. 1985: The late Quaternary history of Hall Land, northwest Greenland. Can. J. Earth Sci. 22, 1394-1408.

England, J. 1987: The late Quaternary history of Hall Land, northwest Greenland: Reply. Can. J. Earth Sci. 24, 374-380.

England, J. \& Bednarski, J. 1986: Postglacial isobases from northern Ellesmere Island and Greenland: new data. Geographie physique Quaternaire 40, 299-305.

England, J. \& Bradley, R. S. 1978: Past glacial activity in the Canadian High Arctic. Science 200, 265-270.

England, J., Bradley, R. S. \& Miller, G. H. 1978: Former ice shelves in the Canadian High Arctic. J. Glaciol. 20, 393-404.

England, J., Bradley, R. S. \& Stuckenrath, R. 1981: Multiple glaciations and marine transgressions, western Kennedy Channel, Northwest Territories, Canada. Boreas 10, 71-89.

Feilden, H. W. 1895: Note on the erratic blocks of Polaris Bay and other localities in North Greenland. Geol. Mag. (2), 4, 378-379.

Funder, S. 1978: Holocene stratigraphy and vegetation history in the Scoresby Sund area, East Greenland. Bull. Grønlands geol. Unders. 129, $66 \mathrm{pp}$.

Funder, S. 1982: $\mathrm{C}^{14}$-dating of samples collected during the 1979 expedition to North Greenland. Rapp. Grønlands geol. Unders. 110, 9-14.

Funder, S. (co-ordinator), Larsen, H. C. \& Fredskild, B. 1989: Quaternary geology of the ice free areas and adjacent shelves of Greenland. In Fulton, R. J. (ed.) Quaternary geology of Canada and Greenland, 741-792. Geological Sur- 
vey of Canada, Geology of Canada, 1 (also Geological Society of America, The Geology of North America K-1).

Funder, S. (ed.) 1990: Late Quaternary stratigraphy and glaciology in the Thule area, Northwest Greenland. Meddr Grønland Geosci. 22, 63 pp.

Funder S. \& Hjort, C. 1980: A reconnaissance of the Quaternary geology of eastern North Greenland. Rapp. Grønlands geol. Unders. 99, 99-105.

Funder S. \& Larsen, O. 1982: Implications of volcanic erratics in Quaternary deposits of North Greenland. Bull. geol. Soc. Denmark 31, 57-61.

Henriksen, N. 1987: Systematic geological mapping in 1985 in central and western North Greenland. Rapp. Gronlands geol. Unders. 133, 5-12.

Higgins, A. K. 1988: Glacier velocities from aerial photographs in North and North-East Greenland. Rapp. Grønlands geol. Unders. 140, 102-105.

Hjort, C. 1981: Present and middle Flandrian coastal morphology in Northeast Greenland. Norsk geog. Tidsskr. 35, 197207.

Hodgson, D. A. 1989: Quaternary stratigraphy and chronology (Queen Elizabeth Islands). In Fulton, R. J. (ed.) Quaternary geology of Canada and Greenland, 741-792. Geological Survey of Canada, Geology of Canada, 1 (also Geological Society of America, The Geology of North America K-1).

Kelly, M. 1973: Radiocarbon dated shell samples from Nordre Strømfjord, West Greenland, with comments on the models of glacio-isostatic uplift. Rapp. Grønlands geol. Unders. 59, $20 \mathrm{pp}$.

Kelly, M. 1980: The status of the Neoglacial in western Greenland. Rapp. Gronlands geol. Unders. 96, $24 \mathrm{pp}$.

Kelly, M. 1985: A review of the Quaternary geology of western Greenland. In Andrews, J. T. (ed.) Quaternary environments. Eastern Canadian Arctic, Baffin Bay and western Greenland, 461-501. Boston: Allen \& Unwin.

Kelly, M. 1986: Quaternary, pre-Holocene, marine events of western Greenland. Rapp. Grønlands geol. Unders. 131, 23 pp.

Kelly, M. \& Bennike, O. 1985: Quaternary geology of parts of central and western North Greenland: a preliminary account. Rapp. Grønlands geol. Unders. 126; 111-116.

Knuth, E. 1981: Greenland news from between $81^{\circ}$ and $83^{\circ}$ North. Folk 23, 91-111.

Koch, L. 1928a: Contributions to the glaciology of North Greenland. Meddr Grønland 65, 181-464.

Koch, L. 1928b: The physiography of North Greenland. In Vahl, H. et al. (ed.) Greenland, vol. 1. The discovery of Greenland, exploration and nature of the country, 491-518. Copenhagen: C. A. Reitzel \& Oxford U.P.

Laursen, D. 1950: The stratigraphy of the marine Quaternary deposits in West Greenland. Bull. Grønlands geol. Unders. 2 (also Meddr Grønland 151, 1), 142 pp.
Meldgaard, M. \& Bennike, O. 1989: Interglacial remains of caribou (Rangifer tarandus) and lemming (Dicrostonyx torquatus(?)) from North Greenland. Boreas 18, 359-366.

Miers, E. J. 1877: Report on the Crustacea collected by the Naturalists of the Arctic Expedition 1875-76. Ann. Mag. Nat. Hist. 20, 52-66 \& 96-110.

Noe-Nygaard, A. 1932: Remarks on Mytilus edulis L. in raised beaches in East Greenland. Meddr Grønland 95(2), 24 pp.

Paterson, W. S. B. 1977: Extent of the late Wisconsin glaciation in northwest Greenland and northern Ellesmere Island: a review of the glaciological and geological evidence. $Q u a$ ternary Res. 8, 180-190.

Petersen, K. S. 1986: Marine molluscs as indicators of former sea-level stands. In Plasche, O. van de (ed.) Sea-level research: a manual for the collection and evaluation of data. 129-155. Norwich: Geo Books.

Retelle, M. J. 1986. Glacial geology and Quaternary marine stratigraphy of the Robeson Channel area, northeastern Ellesmere Island, Northwest Territories. Can. J. Earth Sci. 23, 1001-1012.

Rubin, M. \& Alexander, C. 1960: U. S. Geological Survey radiocarbon dates V. Am. J. Sci., Radiocarbon Suppl. 2, 129-185.

Schiøtte, T. 1989: Marine mollusca from Jørgen Brønlund Fjord, North Greenland, including the description of Diaphana vedelsbyae n. sp. Meddr Grønland Biosci. 28, 24 pp.

Thorson, G. 1933: Investigations on shallow water animal communities in the Franz Joseph Fjord (East Greenland) and adjacent waters. Meddr Gronland 100(2), 69 pp.

Weidick, A. 1971: Quaternary map of Greenland 1:2500000. Copenhagen: Geol. Surv. Greenland.

Weidick, A. 1972: Holocene shorelines and glacial stages in Greenland - an attempt at correlation. Rapp. Gronlands geol. Unders. 41, $39 \mathrm{pp}$.

Weidick, A. 1975: A review of Quaternary investigations in Greenland. Inst. Polar Stud. Rep. 55, 161 pp.

Weidick, A. 1976: Glaciations of northern Greenland - new evidence. Polarforschung 46, 26-33.

Weidick, A. 1977a: A reconnaissance of Quaternary deposits in northern Greenland. Rapp. Grønlands geol. Unders. 85, 21-24.

Weidick, A. 1977b: $\mathrm{C}^{14}$ dating of Survey material carried out in 1976. Rapp. Grønlands geol. Unders. 85, 127-129.

Weidick, A. 1978a: $\mathrm{C}^{14}$ dating of survey material carried out in 1977. Rapp. Grønlands geol. Unders. 90, 119-124.

Weidick, A. 1978b: Comments on radiocarbon dates from northern Greenland made during 1977. Rapp. Grønlands geol. Unders. 90, 124-128.

Weidick, A., Oerter, H., Reeh, N., Thomsen, H. H. \& Thorning, L. 1990: The recession of the Inland Ice margin during the Holocene climatic optimum in the Jakobshavn Isfjord area of West Greenland. Palaeogeogr. Palaeoclimatol. Palaeoecol. (Global Planet. Change Sci.) 82, 389-399. 


\section{Appendix 1 . New radiocarbon data}

Radiocarbon dates of material collected in 1984 by $\mathrm{O}$. Benike and M. Kelly. The samples have been dated at the University of Uppsala, Sweden by accelerator mass spectrometry (samples marked Ua) and at the Scottish Universities Research and Reactor Centre, Britain (sample marked GU). The original dates include a correction for isotopic fractionation relative to $-25 \mathrm{ppt} \delta^{13} \mathrm{C}$. The date for $\mathrm{Ua}-1228$ is based on an assumed $\delta^{13} \mathrm{C}$ value of 0 ppt. The corrected date given bclow include an additional correction for the oceanic reservoir effect using the values recommended by Funder (1982).

GGU 313813: GU-2588. Wuiff Land

$10480 \pm 90$ B.P. $\delta^{l 3} \mathrm{C}=-23.4 \mathrm{ppt}$

Filamentous green algae from lens of silt in $14 \mathrm{~m}$ scction of gravels and diamictons at $72 \mathrm{~m}$ above sea level, northern Wulff Land, $82^{\circ} 23^{\prime} \mathrm{N}, 49^{\circ} 10^{\prime} \mathrm{W}$.

GGU 313882: Ua-1228. Hall Land

$8555 \pm 160$ B.P.

Reservoir corr. 8005 B.P.

Shells of Arca glacialis from section in marine silts at $44 \mathrm{~m}$ above sea level, Alka Elv, western Hall Land, $81^{\circ} 35^{\prime} \mathrm{N}$, $61^{\circ} 10^{\prime} \mathrm{W}$.

GGU 313944: Ua-948. Warming Land

$>40000$ B.P.

Salix twig from section in lacustrine laminated silt and fine sand, $115 \mathrm{~m}$ above sea !evel. Skalhøjene, Warming Land, $81^{\circ} 57^{\prime} \mathrm{N}, 53^{\circ} 38^{\prime} \mathrm{W}$.

Appendix 2. Macrofossils in a $3.5 \mathrm{~m}$ thick Holocene peat deposit, southern Wulff Land (loc. 4l)

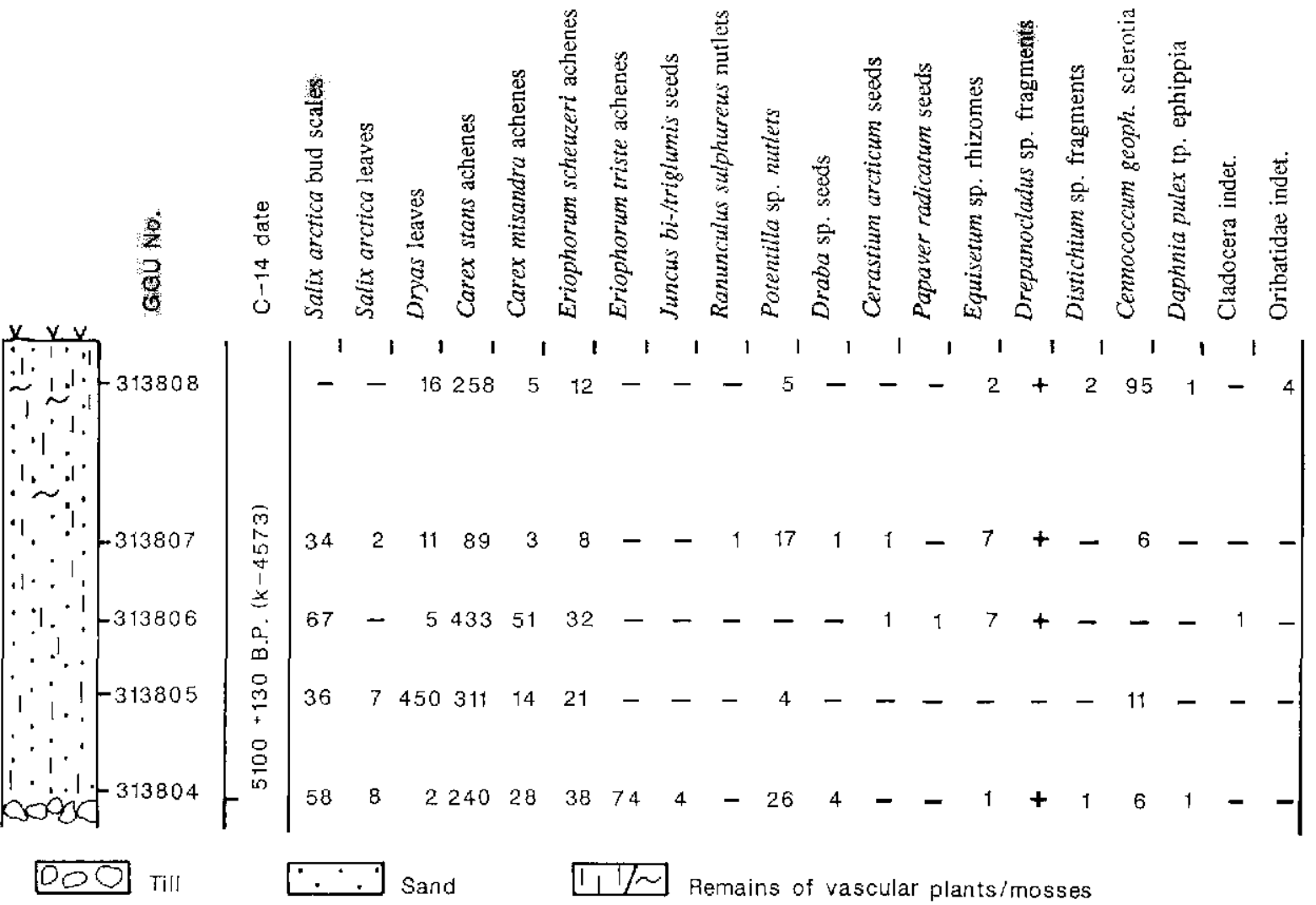


Appendix 3. Evidence for the limit of Nyeboe Land marine transgression

\begin{tabular}{|c|c|c|c|c|c|c|c|}
\hline \multirow[b]{2}{*}{ Locality } & \multirow{2}{*}{$\begin{array}{c}\text { Marine } \\
\text { limit } \\
\text { m a.s.1 }\end{array}$} & \multicolumn{2}{|r|}{ Evidence } & \multirow[b]{2}{*}{ Locality } & \multirow{2}{*}{$\begin{array}{c}\text { Marine } \\
\text { limit } \\
\text { m a.s.1 }\end{array}$} & \multicolumn{2}{|r|}{ Evidence } \\
\hline & & $\begin{array}{l}\text { Height } \\
\mathrm{m} \text { a.s.l. }\end{array}$ & Description & & & $\begin{array}{l}\text { Height } \\
\text { m a.s.l. }\end{array}$ & Description \\
\hline \multirow[t]{4}{*}{1} & $75-127$ & 69 & marine shells & 33 & $67-71$ & $67-71$ & gravel delta terrace \\
\hline & & 75 & delta terrace & 35 & $63-92$ & 63 & gravel delta terrace \\
\hline & & 111 & highest silts & & & 92 & gravel delta terrace \\
\hline & & 127 & back of main delta terrace & 36 & 71 & 71 & gravel delta terrace \\
\hline 2 & c. 120 & 120 & gravel stream delta & & $>78$ & 78 & highest in place shells \\
\hline \multirow[t]{3}{*}{4} & $75-126$ & 75 & highest ?marine silts & 38 & $91-104$ & 91 & gravel delta terrace front \\
\hline & & 126 & gravel bench $W$ of moraine & & & 104 & upper gravel delta terrace front \\
\hline & & 124 & gravel terrace $E$ of moraine & 39 & 72 & 72 & gravel delta terrace \\
\hline \multirow[t]{2}{*}{5} & $>106$ & 82 & highest fossilif. silts off ridge & 40 & 67 & $60-67$ & gravel terrace \\
\hline & & 106 & shells on ridge & 42 & $85-116$ & 85 & highest shell fragments \\
\hline \multirow[t]{2}{*}{7} & 125 & 125 & wash limit on moraine & & & 116 & highest silts \\
\hline & & 125 & gravel bench $E$ of moraine & & & 132 & till bench \\
\hline \multirow[t]{3}{*}{10} & $>76$ & 76 & highest shelss & 44 & 74-93 & 71 & highest shells \\
\hline & & 78 & gravel terrace & & & 74 & highest silts \\
\hline & & 164 & till bench & & & 93 & gravel bench \\
\hline 11 & $<134$ & 134 & kame terrace? & & & 108 & gravel delta terrace front \\
\hline \multirow[t]{4}{*}{13} & $117-124$ & 106 & highest in place shells & 46 & $79-109$ & 79 & highest in place shells \\
\hline & & $111-117$ & gravel terrace & & & 109 & highest silts \\
\hline & & 121 & wash limit at terrace back & 47 & $35-45$ & 35 & highest shells \\
\hline & & 124 & end till ridge & & & 45 & gravel terrace \\
\hline \multirow[t]{4}{*}{14} & $116-124$ & 112 & highest in place shells & 48 & $35-87$ & 35 & gravel terrace \\
\hline & & 119 & highest silts & & & 64 & bench in till \\
\hline & & 121 & negative feature & & & 87 & ice margin feature \\
\hline & & 124 & truncated knoll & 49 & $55-75$ & 55 & gravel delta terrace \\
\hline \multirow[t]{2}{*}{15} & 123 & 116 & highest in place shells & & & 75 & gravel ridge on till \\
\hline & & 123 & negative feature in till & 50 & $>71$ & 71 & gravel delta terrace \\
\hline 16 & 110 & 110 & highest gravel delta terrace & & & 80 & till bench \\
\hline \multirow[t]{2}{*}{17} & 92 & 92 & gravel delta terrace & & & 102 & till bench \\
\hline & & 114 & ?kame terrace & 51 & $>11$ & 11 & highest in place shells \\
\hline \multirow[t]{2}{*}{18} & $72-95$ & 72 & highest silts & & & 28 & small gravel delta terrace \\
\hline & & 95 & gravel delta terrace & & & 85 & till bench \\
\hline \multirow[t]{3}{*}{20} & $>116$ & 104 & highest in place shells & 53 & $71-94$ & 71 & highest in place shells \\
\hline & & 116 & highest silts & & & 73 & gravel delta terrace \\
\hline & & 110 & gravel delta terrace & & & 94 & gravel delta terrace \\
\hline 23 & $>119$ & 119 & highest silts & 54 & $>41$ & 41 & highest in place shells \\
\hline \multirow[t]{2}{*}{26} & $103-122$ & 103 & highest silts & & & 68 & ? marine silts \\
\hline & & 122 & gravel delta & & & 92 & highest silts ?lacustrine \\
\hline \multirow[t]{3}{*}{28} & $97-134$ & 97 & highest shell frgaments & 55 & $61 ?$ & 61 & terrace remnant \\
\hline & & 128 & gravel ridge? & & & & \\
\hline & & 134 & highest silts & & & & \\
\hline \multirow[t]{2}{*}{30} & $102-128$ & 102 & highest silts & & & & \\
\hline & & 128 & gravel delta & & & & \\
\hline \multirow[t]{4}{*}{31} & $109-114$ & $109-113$ & kame delta surface & & & & \\
\hline & & 109 & $\begin{array}{l}\text { highest silts with shell } \\
\text { fragments }\end{array}$ & & & & \\
\hline & & 114 & silts adjacent to moraine & & & & \\
\hline & & 119 & highest silts & & & & \\
\hline
\end{tabular}


(Fig. 1, loc. 43) (GGU 313813)

\section{PLANTS}

Filamentous algae

Cennococcum geophilum Fries

Distichium sp.

Potentilla sp.

Saxifraga oppositifolia L.

Minuartia sp.(?)

\section{ANIMALS}

Oligochaeta

Lepidurus arcticus (Pallas)

Daphnia pulex type

Prionocypris glacialis (G. O. Sars)

Candona subgibba G. O. Sars (?)

Chironominae very common
9 sclerotia

fragments common

nutlets

1 leaf fragment, 2 seeds

seed

some coccoons

a few skeletal remains

numerous ephippia

few shells

few shells

larval head capsules common 
GRØNLANDS GEOLOGISKE UNDERSØGELSE THE GEOLOGICAL SURVEY OF GREENLAND
QUATERNARY MAP OF THE HALL LAND - NANSEN LAND REGION NORTH GREENLAND
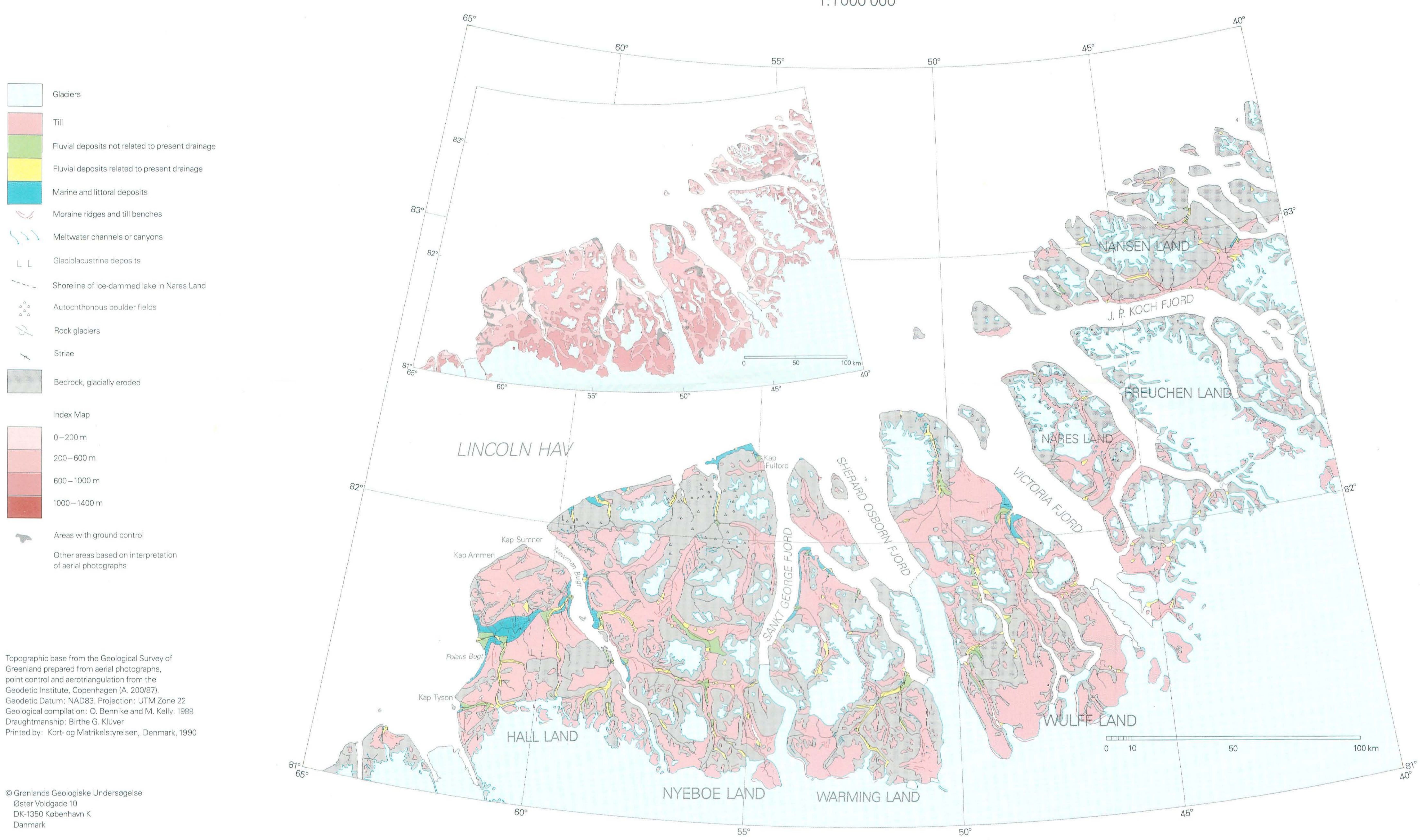